\title{
CRIME AND PUNISHMENT: ASSESSING DETERRENCE THEORY IN THE CONTEXT OF SOMALI PIRACY
}

\author{
Yvonne M. DutTon*
}

\section{INTRODUCTION}

Deterrence theory predicts that the credible threat of punishment from a well-enforced criminal justice system will reduce crime: it will dissuade individuals from becoming criminals in the first place or from continuing with a life of crime. ${ }^{1}$ Indeed, one primary justification for creating and maintaining both national and international justice systems is the belief that they deter crime. ${ }^{2}$ Individuals should view crime as costly because it brings the potential for punishment in the form of a public arrest, prosecution, and sentence. If the potential for punishment is sufficiently certain and severe, the hoped-for result is that rational

* Associate Professor of Law, Indiana University Robert H. McKinney School of Law. Ph.D. 2011, University of Colorado at Boulder; M.A. 2008, University of Colorado at Boulder; J.D. 1991, Columbia University; B.A. 1989, Columbia University.

1. See, e.g., Raymond Paternoster, How Much Do We Really Know About Criminal Deterrence?, 100 J. CRIM. L. \& CRIMINOLOGY 765, 766 (2010) ("The concept of deterrence is quite simple-it is the omission of a criminal act because of the fear of sanctions or punishment."); Gary S. Becker, Crime and Punishment: An Economic Approach, 76 J. Pol. Econ. 169, 204 (1968) ("The anticipation of conviction and punishment reduces the loss from offenses and thus increases social welfare by discouraging some offenders.").

2. See, e.g., Harmelin v. Michigan, 501 U.S. 957, 1007-08 (1991) (Kennedy, J., concurring) (noting that deterrence is one of the "first purposes of criminal law"); M. Cherif Bassiouni, Combating Impunity for International Crimes, 71 U. Colo. L. Rev. 409, 410 (2000) (noting that one of the purposes of pursuing justice and accountability is to prevent and deter future conflicts); Rome Statute of the International Criminal Court pmbl., July 17, 1998, 2187 U.N.T.S. 90 [hereinafter Rome Statute] (stating that a goal of the International Criminal Court is to contribute to the prevention of mass atrocities); Prosecutor v. Rutaganda, Case No. ICTR-96-3-T, Judgement and Sentence, para. 455 (Dec. 6, 1999), http:// www.unictr.org/Portals/0/Case/English/Rutaganda/judgement/991206.pdf (stating that prosecuting international crimes can "dissuade for ever, others who may be tempted in the future to perpetrate such atrocities by showing them that the international community shall not tolerate the serious violations of international humanitarian law and human rights"); Michael P. Scharf, The Prosecutor v. Dusko Tadic: An Appraisal of the First International War Crimes Trial Since Nuremberg, 60 Alb. L. Rev. 861, 868 (1997) (quoting former tribunal prosecutor Richard Goldstone as suggesting that international criminal tribunals can aid in deterring future atrocities). 
individuals will conclude that "crime does not pay." They should conclude that the costs of criminal behavior outweigh its benefits. ${ }^{3}$

Nevertheless, how does this theory apply to Somali piratescriminals who since the mid-2000s have been hijacking ships and holding innocent crew members hostage until they are paid a hefty ransom? ${ }^{4}$ This Article specifically examines deterrence theory in the context of Somali piracy to contribute to the ongoing and vibrant discussion about how to "solve" the global threat posed by Somali pirates. ${ }^{5}$ In doing so, it shows that Somali pirates are for the most part rational actors who could be positively influenced by a credible threat of punishment to eschew a life of crime.

Thus far, however, any such credible threat to rigorously and regularly prosecute acts of maritime piracy has been largely absent. The international community has spent billions of dollars on naval patrols that roam the waters off the Somali coast to help protect ships from being attacked. ${ }^{6}$ Although those navies have been successful in thwarting a number of attacks, they have tended to release the pirates they capture rather than to transfer them for prosecution. ${ }^{7}$ According to a report by Jack Lang, Special Adviser on Legal Issues Related to Piracy off the Coast of Somalia (Lang

3. See A. Mitchell Polinsky \& Steven Shavell, The Economic Theory of Public Enforcement of Law, 38 J. Econ. Literature 45, 47 (2000) (explaining logic of deterrence theory).

4. See, e.g., Reg'l Vice-Presidency for Afr., The World Bank, The Pirates of Somalia: Ending the Threat, Rebuilding a Nation 94 (2013) [hereinafter 2013 World BANK REPORT] (stating that since the mid-2000s, Somali pirates have held almost four thousand crew members hostage); see generally Oceans Beyond Piracy, One Earth Future Found., The Economic Cost of Somali Piracy 10-13 (2012), available at http://oceans beyondpiracy.org/sites/default/files/attachments/View\%20Full\%20Report_1.pdf [hereinafter ECONOMic Cost 2012] (discussing ransom costs of piracy).

5. See, e.g., 2013 World BANK Report, supra note 4, at 173 (suggesting that solving the problem of Somali piracy requires a focus on the stakeholders who gain from piracy, and that the world community should help facilitate incentive packages from the Somali government in exchange for a commitment from local stakeholders not to support piracy); Stig Jarle Hansen, Norwegian Inst. for Urban \& Reg'l Research, Piracy in the Greater Gulf of Aden: Myths, Misconception and Remedies 56 (2009), available at http:/ /www.nibr.no/filer/2009-29-ny.pdf (suggesting that focusing on improving local institutions in the Puntland area of Somalia would aid in solving the problem of Somali piracy).

6. Economic Cost 2012, supra note 4, at 2, 20.

7. Special Adviser to the Secretary-General on Legal Issues Related to Piracy off the Coast of Somalia, U.N. Secretary-General, Annex to the Letter from the Secretary-General Addressed to the President of the Security Council, para. 43, U.N. Doc. S/2011/30 (Jan. 25, 2011) [hereinafter Lang Report]; see also International Efforts to Combat Maritime Piracy: Hearing Before the Subcomm. on Int'l Orgs., Human Rights $\mathcal{E}$ Oversight of the H. Comm. on Foreign Affairs, 111th Cong. 27 (2009) (statement of Rear Admiral William Baumgartner, U.S. Coast Guard) (explaining that even when pirates are caught in the act and apprehended, they are more typically released and permitted to continue their illegal activities rather than brought to justice). 
Report), by 2011, the international community was releasing more than ninety percent of captured pirates. ${ }^{8}$ Therefore, the message to pirates is that even when they are unfortunate enough to be "caught in the act," the most likely costs of their illegal activities are those associated with having to seek out a new target. ${ }^{9}$ That message could change if the international community were prepared to prosecute a great majority of captured pirates.

This Article argues that increasing the threat of prosecutions is a necessary component to solving the problem of maritime piracy because the increased threat has the potential to deter Somali piracy. The Article recognizes that Somali pirates may experience certain "push" factors that increase the lure of piracy as a way to earn a living. For example, Somalia is a poor country characterized by weak political and legal institutions in the areas where piracy is most prevalent. ${ }^{10}$ Neither of these factors, however, detracts from the potential deterrent effect of a credible threat to punish, rather than release, those who hijack ships and take hostages for ransom.

First, even though Somalia is a poor country, evidence suggests that Somali pirates are motivated by greed: they hijack ships to obtain fast cars, big houses, and other riches. ${ }^{11}$ They choose piracy as a career partly because the potential rewards are high, especially considering the likelihood of prosecution if caught. ${ }^{12}$ In other words, not every Somali is designed to be lured by piracy regardless of the costs in order to put food on the table. In fact, other solutions to the problem of maritime piracy fall short because they fail to account for greed as a motivating factor. For example, strategies aimed at containing piracy by thwarting attacks help protect inno-

8. Lang Report, supra note 7, para. 43.

9. Even in domestic jurisdictions, of course, not all criminals are captured and brought to justice. However, it seems unlikely that, in any domestic jurisdiction, ninety percent of captured criminals would not be prosecuted. Indeed, some evidence bears out this intuition. See, e.g., U.S. Dep't of Justice, Exec. Office for the U.S. Att'y, United States Attorneys' Annual Statistical Report 7 (2011) (showing that in 2011, U.S. Attorneys' offices had received 163,908 criminal referrals from law enforcement agencies, of which they had declined a total of 25,102 for lack of sufficient evidence, among other things-a fifteen percent declination rate); NYS Div. Criminal Justice Servs., New York State Adult Arrests Disposed (2013), available at http://www.criminaljustice.ny.gov/ crimnet/ojsa/dispos/nys.pdf (last accessed Feb. 3, 2014) (showing that between 2008 and 2012, more than sixty-six percent of felony arrests in New York state resulted in convictions).

10. See Helen Jane Martin, Somalia: Why Are We Failing the Failed States?, Pinpoint Pol. (May 10, 2012), http://pinpointpolitics.co.uk/somalia-why-are-we-failing-the-failed-states.

11. See infra notes 33-45 and accompanying text.

12. See discussion infra Part II.D (discussing low prosecution rates). 
cent seafarers, but they are unlikely to convince pirates to abandon their quest for riches if accompanied only by the threat of losing their weapons or skiffs. ${ }^{13}$ Strategies aimed at helping Somalia's youth learn skills to earn an honest living also have merit. ${ }^{14}$ However, the would-be pirates seeking riches will not be persuaded to settle for the more modest wages they can earn from honest work unless hijacking ships is accompanied by a greater threat of downside costs.

Second, for Somalia's weak or corrupt institutions, increasing the credible threat of sanctions through international prosecutions of captured pirates can help neutralize this push factor. Through prosecutions, the international community can send a message that some of Somalia's own institutions may be currently unwilling or unable to send: hijacking ships is worthy of moral condemnation. ${ }^{15}$ If pirates heed that message, then the institutions in Somalia that benefit from piracy should lose the opportunity to extract bribes for protecting pirates. ${ }^{16}$ As a result, those institutions also could be pushed in a different and better direction. This is not to suggest abandoning the solutions aimed at instilling a respect for the rule of law into the regions most affected by piracy by improving the function of local institutions. ${ }^{17}$ Nevertheless, changing entrenched policies and practices can be time consuming and difficult, especially if some individuals overseeing those policies and practices have a stake in maintaining the status quo of piracy and the riches it can bring. ${ }^{18}$ Increasing the credible threat of prosecutions could well complement any solutions that aim to improve local institutions that could be used to fight piracy.

Part II of this Article describes Somali piracy and the political and social context in which it presented itself as a global threat in

13. See discussion infra Part II.C.

14. See, e.g., United Nations Office on Drugs \& Crime (UNODC), Counter Piracy Programme: Support to the Trial and Related Treatment of Piracy Suspects 3 (2012) (describing a U.N. Office on Drugs and Crime (UNODC) program, which provides opportunities for young Somali men to learn skills to support an economically viable livelihood as a deterrent to engaging in maritime piracy).

15. See discussion infra Part III.

16. See discussion infra Part II.D.

17. See HANSEN, supra note 5, at 56-61 (emphasizing the need to improve local institutions in the Puntland area of Somalia, while also noting that all efforts would have to be cognizant of the difficulties in overcoming ingrained corruption and the stake that some officials have in continuing to profit from the bribes paid by pirates).

18. Somali piracy has been such a lucrative business that piracy proceeds have well exceeded the entire budget of the Puntland region of Somalia where piracy has been most active. See Lang Report, supra note 7, para. 23; Lauren Ploch et Al., Cong. Research Serv., R40528, Piracy off the Horn of Africa 5-6 (2009) [hereinafter Ploch 2009]. 
the mid-2000s. It also discusses the Somali piracy business model and how the desire for money and profits drives pirates to hijack ships and hold innocent seafarers hostage until the pirates can secure their huge ransom payments. Part III explains deterrence theory and discusses some of its limitations relevant to whether Somali pirates can be positively influenced by the credible threat of a well-enforced legal sanctions regime. In Part IV, the Article specifically analyzes deterrence theory in the context of Somali piracy. Part $\mathrm{V}$ concludes by recommending the international community to commit to regularly prosecuting pirates and addresses some objections to that proposed approach.

\section{Somali Piracy and the International Community's ANTIPIRACY EFFORTS}

\section{A. The Somali Pirates and the Rise of Their Lucrative Illegal Enterprise}

Maritime piracy has been around since ships took to the seas. ${ }^{19}$ The Somali coast itself has experienced intermittent and smallscale pirate activity since the 1950 s. ${ }^{20}$ Yet, Somali piracy began on a grand scale only in the mid-2000s after a tsunami caused further damage to the already destabilized country. ${ }^{21}$ The rise of piracy thereafter was meteoric. In 2002, attacks by Somali pirates accounted for only 7.5 percent of the attacks reported worldwide; by 2011, reports indicate that Somali pirates were responsible for more than half of the world's attacks. ${ }^{22}$ Pirate attacks were so frequent that by 2009, one actual or attempted attack was reported every twenty-nine hours. ${ }^{23}$ Between 2005 and 2012, Somali pirates staged some 1068 attacks; held hostage at least 3741 seafarers of 125 different nationalities; and received upwards of $\$ 300$ million in ransom monies. ${ }^{24}$ The figures cited above should leave no doubt why the media, the public, organizations, and the world's leaders came to view Somali piracy as a significant threat not only to the

19. Douglas R. Burgess, Jr., Hostis Humani Generi: Piracy, Terrorism and a New International Law, 13 U. Miami Int'L \& Comp. L. Rev. 293, 301 (2006).

20. 2013 World Bank Report, supra note 4, at 87.

21. See, e.g., Lang Report, supra note 7, para. 12 (asserting that the absence of State structures capable of protecting the country's marine resources and combating the criminal practices of pirates led to the resurgence of piracy, especially starting in 2005, in the aftermath of the tsunami which devastated the Puntland coastline).

22. 2013 World Bank Report, supra note 4, at 2.

23. Peter Chalk, Piracy off the Horn of Africa: Scope, Dimensions, Causes and Responses, 16 Brown J. World AfF. 89, 90-91 (2010).

24. 2013 World Bank Report, supra note 4, at 1. 
world's seafarers but also to the international community more broadly. ${ }^{25}$

Yet who are the Somali pirates and why did they begin attacking ships so frequently in the mid-2000s? Pirates like to claim that they are just innocent fishermen who turned to piracy as a way to defend against foreign vessels that were illegally fishing and dumping toxic waste in the country's territorial waters. ${ }^{26}$ There is little truth to this justification, however. It is true that Somalia has been unable to fully protect its waters since being plagued by civil war beginning in the $1990 \mathrm{~s} .{ }^{27}$ Some reports indicate that foreign vessels stole more than $\$ 100$ million annually in seafood from Somalia's waters in the early 2000s. ${ }^{28}$ Yet there is no actual proof that links the phenomenon of Somali piracy to illegal fishing. ${ }^{29}$ As Jay Badahur notes in his journalistic account of Somali piracy, although pirates like to use the excuse of illegal fishing to justify their actions, they hijack for ransom almost exclusively the large commercial vessels transporting cargo. ${ }^{30}$ Evidence supports that finding-only 6.5 percent of Somali pirate attacks have been against fishing vessels. ${ }^{31}$

25. See, e.g., Blocking Property of Certain Persons Contributing to Conflict in Somalia, Exec. Order No. 13,536, 75 Fed. Reg. 19,869 (Apr. 12, 2010) (quoting President Obama that acts of piracy and armed robbery off the coast of Somalia pose "an unusual and extraordinary threat to the national security and foreign policy of the United States"); MacKenzie C. Babb, Somalia: U.S. Combats Growing Global Problem of Maritime Piracy, ALLAfricA (Mar. 31, 2011), http://www.allafrica.com/stories/201104190291.html (quoting U.S. Assistant Secretary of State for Political-Military Affairs, Andrew Shapiro, that "piracy off the Horn of Africa threatens not just specific ships, but has broader strategic implications"); UNODC, Testimony to the United States House of Representatives Foreign Affairs Subcommittee on International Organizations, Human Rights and Oversight: Fighting Piracy on Land and at Sea (May 14, 2009), http://www.unodc.org/unodc/en/aboutunodc/speeches/2009-14-05.html (noting that Somali piracy threatens regional stability and the security interests of U.N. member states).

26. Lang Report, supra note 7, paras. 12-13; Robert Young Pelton, Somali Pirates' Rich Returns, Bloomberg Businessweek (May 12, 2011), http://www.businessweek.com/ magazine/content/11_21/b4229064090727.htm.

27. 2013 World Bank Report, supra note 4, at 140.

28. Lauren Ploch et al., Cong. Research Serv., R40528, Piracy off the Horn of Africa 9 (2011) [hereinafter Ploch 2011] (referencing a report that during 2003-2004, Somalia lost $\$ 100$ million due to illegal fishing); Ishaan Tharoor, How Somalia's Fishermen Became Pirates, Time (Apr. 18, 2009), http://www.time.com/time/world/article/ $0,8599,1892376,00 . h t m l$ (referencing a report that foreign vessels stole about $\$ 300$ million annually of seafood from Somalia's waters in the early 2000s).

29. Lang Report, supra note 7, para. 13.

30. Jay Badahur, The Pirates of Somalia: Inside Their Hidden World 20 (2011).

31. Foreign Affairs Committee, Piracy off the Coast of Somalia, 2010-12, H.C. 1318, I 5 (U.K.) [hereinafter Foreign Affairs Committee 2012 Report]. 
In other words, Somali pirates are not innocent fishermen attacking ships to send a political message. ${ }^{32}$ The reality is much different. Somali piracy is a big business: it is carried out by wellorganized pirate gangs ${ }^{33}$ motivated by opportunity and profit. Opportunity presents itself in a couple of ways. First, Somalia borders waters through which more than thirty thousand ships transporting cargo from east to west pass each year. ${ }^{34}$ Second, Somalia offers the potential for criminal enterprises to exist and thrive because some areas are without effective local government and law enforcement institutions. ${ }^{35}$ The profit motive is apparent from the pirates' preference for targeting the commercial ships willing to pay hefty ransoms in exchange for the safe return of cargo and crew. ${ }^{36}$ In 2011 , the average ransom paid to pirates was about $\$ 5$ million. ${ }^{37}$

Hefty ransoms lure those who organize and invest in piracy and those who actually hijack the ships and watch over hostages. In exchange for providing the equipment and start-up capital to fund the pirate gangs who search for a viable target, kingpins and investors receive the greatest share of the ransom proceeds. ${ }^{38}$ The onthe-water pirates-typically men of the ages between fifteen and

32. Id. I 6 (stating that the vast majority of Somali pirates were never fishermen and are instead lured by the potential for profits); Lang Report, supra note 7, para. 13 (noting that Somali piracy is not undertaken to protect coastal waters and instead has "become an organized, lucrative and attractive criminal activity"); Pelton, supra note 26 (reporting that although pirates claim to be innocent fisherman, the facts demonstrate they hijack because of the lure of hefty ransom payments).

33. See, e.g., Chalk, supra note 23, at 91 (stating that Somali pirates are organized along clan lines into gangs that report to leaders who finance the attacks); GeOpOLICITY, The Economics of Piracy: Pirate Ransoms \& Livelihoods off the Coast of Somalia 8 (2011), available at http://www.geopolicity.com/upload/content/pub_1305229189_ regular.pdf (referencing four main pirate gangs in Somalia); James Kraska, Coalition Strategy and the Pirates of the Gulf of Aden and the Red Sea, 28 Comp. Strategy 197, 199 (2009) (referencing the organized kingpins who finance and organize Somali pirate hijackings and receive a large share of the ransom proceeds from attacks).

34. Ploch 2009, supra note 18, at 9.

35. See id. at 7-8.

36. See id. at 8; Lang Report, supra note 7, para. 13; Pelton, supra note 26.

37. Foreign Affairs Committee 2012 Report, supra note 31, II 111 (stating the average ransom paid to pirates climbed from about $\$ 600,000$ in 2007 to about $\$ 5$ million in 2011). Of course, some ransoms are significantly higher. For example, Somali pirates were paid $\$ 13.5$ million in ransom to release the $M V$ Irene, a supertanker carrying two million barrels of Kuwaiti oil destined for the United States and estimated to be worth $\$ 200$ million. Oceans Beyond Piracy, One Earth Future Found., The Economic Cost of Somali Piracy 11 (2011), available at http://oceansbeyondpiracy.org/sites/default/files/ economic_cost_of_piracy_2011.pdf [hereinafter Economic Cost 2011].

38. See The World Bank, Pirate Trails: Tracking the Illicit Financial Flows from Pirate Activities off the Horn of Africa 46-47 (2013), available at http://siteresources .worldbank.org/EXTFINANCIALSECTOR/Resources/Pirate_Trails_World_Bank_UNO 
thirty with little education and few skills ${ }^{39}$-also receive a share. ${ }^{40}$ Those pirates can earn between $\$ 10,000$ and $\$ 15,000$ for participating in a successful attack ${ }^{41}$ and perhaps more than $\$ 50,000$ in a year. ${ }^{42}$ Some on-the-water pirates may earn even more for their participation-up to $\$ 75,000$ for their role in an attack. ${ }^{43}$ This is a lot of money in a country plagued by poverty where individuals face both low-employment prospects and low-earning potential. ${ }^{44}$ In fact, Somalia's youth unemployment rate is sixty-seven percent, and the median income is about $\$ 600$ per year. ${ }^{45}$ With one successful hijacking, however, the men who have chosen the life of a pirate become rich.

Indeed, although poverty may be a factor helping to push some men to choose piracy as a career, evidence also suggests they are motivated by greed and the desire to become rich. ${ }^{46}$ As one report based on focus groups conducted in Somalia concludes, for these men, "piracy offers the possibility of getting rich quick and enjoying associated benefits of a more affluent lifestyle, marriage and increased khat use." 47 Others offer a similar picture of the "typical" pirate lured by easy money and its apparent rewards. President Abdirahman Mohamed Farole of Puntland ${ }^{48}$ states that the pirates drive around in expensive cars, host lavish parties, and have

DC_Interpol_report.pdf [hereinafter PIRATE TRAILs] (stating that financiers reportedly receive between thirty and seventy-five percent of the ransom payments).

39. Foreign Affairs Committee 2012 Report, supra note 31, II 6.

40. 2013 World Bank Report, supra note 4, at 112; A Pirate's Life Is Good in Somalia, WAsh. Times, Dec. 17, 2009, http://www.washingtontimes.com/news/2009/dec/17/insomalia-a-pirates-life-for-me / ?page=all.

41. 2013 World Bank Report, supra note 4, at 112.

42. Geopolicity, supra note 33, at 12 .

43. Pirate Trails, supra note 38 , at 45 .

44. Id. at 28.

45. See Somalia, CIA World FActBook, https://www.cia.gov/library/publications/theworld-factbook/geos/so.html (last visited Mar. 3, 2014).

46. See Pirate Trails, supra note 38, at 11. Indeed, pirates interviewed for a 2013 World Bank study admitted that they got into piracy because they were attracted by the money it offered. $I d$.

47. Foreign Affairs Committee 2012 Report, supra note 31, II 6 (quoting a report prepared by Saferworld, a nongovernmental organization working within Somalia). Khat is a leafy plant that acts as a stimulant when chewed, producing a mild state of euphoria. Pirate Trails, supra note 38, at 71. While considered a controlled substance by some countries, it is legal in Somalia, and has been chewed in that country for thousands of years. Kenya is the major supplier of khat to its neighbor, Somalia.

48. Puntland is located in northeastern Somalia and is home to about one-third of the country's population. Pirate Trails, supra note 38, at 23 n.1. 
a steady supply of khat. ${ }^{49}$ A 2013 World Bank study similarly reports that most lower-level pirates spend their proceeds on cars, khat, alcohol, and sex workers or trafficked girls. ${ }^{50}$ Ordinary villagers and some religious leaders are not necessarily pleased by the pirate lifestyle characterized by "big houses, fast cars, and easy drugs." 51 Pirates, however, are not loath to brag about their "easy money."52 One successful nineteen-year-old pirate told a reporter that he had gone from living on the street to owning a big house and a large truck by participating in only two ship hijackings. ${ }^{53}$

\section{B. Somali Piracy Methods and Tactics}

Somali pirates prey on the huge amount of commercial shipping that passes through the waters off their country's coastline, including the Gulf of Aden, a relatively constrained waterway close to Somalia's northern shore. ${ }^{54}$ Nevertheless, Somali pirates have also demonstrated that they are capable of mounting attacks in the Indian Ocean up to one thousand nautical miles out to sea. ${ }^{55}$ They operate from "mother ships"-large fishing vessels that pirates typically acquire through other acts of piracy. ${ }^{56}$ The large and slowmoving commercial vessels are often no match for the pirate teams who approach on any number of high-speed maneuverable skiffs powered with large outboard motors. ${ }^{57}$ In many instances, pirates are able to board the ship and take hostages within fifteen to thirty

49. Pelton, supra note 26. In this statement, President Farole appears critical of the pirates. Some, however, have accused him of being in league with the pirates. HANSEN, supra note 5 , at 57 .

50. Pirate Trails, supra note 38, at 45; see also Badahur, supra note 30, at 197 (describing the tendency of the pirates to use their share of the expected ransom payment as credit to go on spending binges immediately after they successfully hijacked a ship); Scott Baldauf, Pirates, Inc.: Inside the Booming Somali Business, Christian Sci. Monitor (May 31, 2009), http://www.csmonitor.com/World/Africa/2009/0531/p06s03-woaf.html/ (page)/4 ("It is the sudden wealth-Somali 'bling'-that proves an irresistible draw for young pirates.").

51. A Pirate's Life Is Good in Somalia, supra note 40.

52. $I d$.

53. Id.

54. Ploch 2009, supra note 18 , at 9.

55. Chalk, supra note 23, at 90-91 (reporting that Somali pirates have staged attacks as far as five hundred to one thousand miles out to sea); Thaine Lennox-Gentle, Piracy, Sea Robbery, and Terrorism: Enforcing Laws to Deter Ransom Payments and Hijacking, 37 TransP. L.J. 199, 208 (2010) (discussing a Somali pirate attack that occurred approximately one thousand nautical miles off the Somali coast).

56. See Ploch 2011, supra note 28, at 10 (explaining the use of mother ships to facilitate hijackings further out to sea).

57. See Kurt Bodewig, The Role of the European Union in Combating Piracy, KurT-BodeWIG.DE (Apr. 9, 2009), http://www.kurt-bodewig.de/node/39. 
minutes of appearance. ${ }^{58}$ Armed with AK-47 rifles and rocket-propelled grenade launchers, Somali pirates have managed to successfully commandeer some of the world's largest supertankers. ${ }^{59}$ As of May 2012, Somali pirates had taken 3741 crew members hostage from 125 countries. ${ }^{60}$ Reports also indicate that between eightytwo and ninety-seven seafarers have died as a result of Somali piracy, either during attacks or during captivity with poor treatment. ${ }^{61}$

As noted above, Somali pirates employ a lucrative hijack-for-ransom business model for several reasons. First, the pirates do not have a viable market to sell the ships' cargo. ${ }^{62}$ Second, Somali pirates also have the unique ability to anchor the hijacked ships in safe harbors in lawless Somalia with financial support from government officials, business people, clan elders, and members of local communities, among others. ${ }^{63}$ The World Bank has pointed to twenty-six different preferred anchoring points, with six of them the most active. ${ }^{64}$ In these safe harbors, the pirates are able to hire ground crews to protect the ship from rescue attempts or competing gangs. ${ }^{65}$ They supply each ground crew with water, food, and khat during their service. ${ }^{66}$ The existence of these safe sanctuaries allows Somali pirates to hold their hostages for a long period until they can coerce ship owners to accede to their ransom demands. ${ }^{67}$ The pirates have been known to take their time during the ransom negotiation process and hold hostages for as long as 1178 days. ${ }^{68}$

58. See Ploch 2009, supra note 18, at 10.

59. See, e.g., Chalk, supra note 23, at 92-93 (reporting on the capture of the Saudi $M V$ Sirius Star, a ship that is three times the size of an aircraft carrier); Somali Pirates Capture Supertanker, \$150M of Oil, USA TODAY (Feb. 10, 2011, 1:41 AM), http://usatoday30.usa today.com/news/world/2011-02-09-pirates-hijack-supertanker_N.htm (reporting the capture of the Greek supertanker MV Irene); Somali Pirates Release Greek Owned VLCC, Hijack German Cargo Ship the Next Day, Mar. Executive (Apr. 11, 2011), http://www.maritimeexecutive.com/article/somali-pirates-release-greek-owned-vlcc-mv-irene-sl (reporting the capture of the MV Susan K, a German cargo ship).

60. 2013 WORLD BANK RePORT, supra note 4 , at 4.

61. Id. at xxiii.

62. Id. at xxiv.

63. Id. at xxiv, 109-10.

64. Id. at 92 .

65. Id.

66. Id. at xxiv, 92-93.

67. Id. at xxii; see also Catherine E. Shoichet \& Neda Farshbaf, Ship Crew Held for 1,000 Days Rescued off Coast of Yemen, CNN (Dec. 24, 2012, 9:16 AM), http://www.cnn.com/2012/ 12/24/world/africa/somalia-pirate-rescue.

68. 2013 World BANk Report, supra note 4, at xxii; see also Shoichet \& Farshbaf, supra note 67 (describing the ordeal of the crew of the MV Iceberg who pirates held for one thousand days while subsisting on water and rice). 
Finally, the potential for rich rewards is the overarching reason. Somali pirates target the large commercial ships precisely because their owners have the resources and incentive to pay huge ransoms in exchange for the release of their cargo and crew. ${ }^{69}$ The average ransom in 2011 was $\$ 5$ million, ${ }^{70}$ but some ransom payments have well exceeded that amount over the years. For example, in 2011, Somali pirates received $\$ 13.5$ million in exchange for the release of the $M V$ Irene, a supertanker carrying a twenty-five-member crew and two million barrels of oil. ${ }^{71}$ Somali pirates also received about $\$ 10$ million in ransom to release a South Korean supertanker, the Samho Dream. ${ }^{72}$

\section{The Fight Against Somali Piracy: Defensive Measures}

Ship owners and states have employed a variety of tactics to ward off attacks by Somali pirates. As an initial matter, many ship owners follow the maritime industry's "best management practices."73 These are a set of guidelines outlining a series of passive defensive measures designed to make a ship less likely to fall prey to a pirate attack. ${ }^{74}$ For instance, the guidelines encourage ships to install alarms and closed circuit televisions so that they will be warned of an imminent attack. ${ }^{75}$ They also warn ships to arm themselves with nonlethal weapons such as high-power fire hoses and razor-wire barriers to repel pirates from boarding the ship. ${ }^{76}$ In addition, the guidelines emphasize the need for ships to register with interna-

69. Jeffrey Gettleman, Money in Piracy Attracts More Somalis, N.Y. Times, Nov. 9, 2010, http://www.nytimes.com/2010/11/10/world/africa/10somalia.html.

70. Foreign Affairs Committee 2012 Report, supra note 31, II 111.

71. Economic Cost 2011, supra note 37, at 11.

72. Gettleman, supra note 69.

73. See, e.g., Int'l Maritime Org. [IMO], Piracy and Armed Robbery Against Ships in Waters off the Coast of Somalia: Best Management Practices to Deter Piracy in the Gulf of Aden and off the Coast of Somalia Developed by the Industry, at Annex 2, IMO Doc. MSC.1/Circ.1335 (Sept. 29, 2009) [hereinafter BMP2]; IMO, Piracy and Armed Robbery Against Ships in Waters off the Coast of Somalia: Best Management Practices to Deter Piracy off the Coast of Somalia and in the Arabian Sea Area Developed by the Industry, at Annex 2, IMO Doc. MSC.1/Circ.1337 (Aug. 4, 2010) [hereinafter BMP3] (revoking and replacing Circular 1335); IMO, Piracy and Armed Robbery Against Ships in Waters off the Coast of Somalia: Best Management Practices for Protection Against Somalia Based Piracy, at Annex 2, IMO Doc. MSC.1/Circ.1339 (Sept. 14, 2011) [hereinafter BMP4] (revoking and replacing Circular 1337 from 2010).

74. See generally BMP2, supra note 73; BMP3, supra note 73; BMP4, supra note 73.

75. See, e.g., BMP3, supra note 73, at 21-23; see also Foreign Affairs Committee 2012 REPORT, supra note 31, If 24 (generally describing some best management practice guidelines); Lang Report, supra note 7, para. 34 (same).

76. See, e.g., BMP2, supra note 73, at 7; BMP3, supra note 73, at 27-30; see also ForeigN Affairs Committee 2012 Report, supra note 31, I 24 (generally describing some best management practice guidelines); Lang Report, supra note 7, para. 34 (same). 
tional and regional monitoring agencies so navies or other counterpiracy teams are able to assist in the event of an attack. ${ }^{77}$

The world's navies also have been patrolling pirate-infested waters to protect ships against attacks. Starting in 2007, some countries began offering naval escorts to World Food Program ships delivering humanitarian aid. ${ }^{78}$ In total, those naval escorts have accompanied about 150 vessels carrying essential humanitarian assistance. ${ }^{79}$ By late 2008, countries also began contributing naval resources to conduct general counterpiracy patrols. ${ }^{80}$ Multinational naval forces (Combined Task Forces 150, 151, and 152) involving twenty-seven different states have been operating in the Gulf of Aden, the Arabian Sea, and the Indian Ocean to disrupt and suppress acts of piracy. ${ }^{81}$ These forces have been joined by others, such as the E.U. combined naval force (Atalanta). ${ }^{82}$ The North Atlantic Treaty Organization (NATO) also has sent ships on antipiracy missions to the Horn of Africa. ${ }^{83}$ Other states, including Russia, China, India, South Korea, Japan, Malaysia, and Singapore, have complemented these multinational operations by sending their own ships to patrol the waters off the Somali coast. ${ }^{84}$ In total, between ten and sixteen naval ships conduct antipiracy missions in the Gulf of Aden and the Indian Ocean on any given day ${ }^{85}$ at a cost of more than $\$ 1$ billion annually. ${ }^{86}$

Notwithstanding these antipiracy efforts, Somali pirate attacks remained a constant threat to passing ships. The International Maritime Bureau (IMB) Piracy Reporting Centre figures show that worldwide pirate attacks between January 2007 and December 2011 numbered 1850 in total. ${ }^{87}$ Attacks during 2009, 2010, and

77. See, e.g., BMP2, supra note 73, at 9; BMP3, supra note 73, at 11 ; see also ForeIGN Affairs Committee 2012 Report, supra note 31, I 24 (generally describing some best management practice guidelines); Lang Report, supra note 7, para. 34 (same).

78. See, e.g., Bodewig, supra note 57; Roger Middleton, Piracy in Somalia: Threatening Global Trade, Feeding Local Wars 7 (2008), available at http://www.chathamhouse .org/files/12203_1008piracysomalia.pdf.

79. See, e.g., U.N. Secretary-General, Report of the Secretary-General Pursuant to Security Council Resolution 2020 (2011), U.N. Doc. S/2012/783 (Oct. 22, 2012).

80. See, e.g., Foreign Affairs Committee 2012 Report, supra note 31, at II 44.

81. See id.

82. Id.; see also Chalk, supra note 23, at 98.

83. Chalk, supra note 23, at 98; PlOCH 2011, supra note 28, at 26.

84. See, e.g., Foreign Affairs Committee 2012 Report, supra note 31, II 44.

85. ECONOMic Cost 2011, supra note 37, at 25.

86. See Economic Cost 2012, supra note 4, at 13-15; Economic Cost 2011, supra note 37 , at 27 .

87. See Int'l Chamber of Commerce, Int'l Mar. Bureau, Piracy and Armed Robbery Against Ships: Report for the Period 1 January-31 December 2011, at 5-6 (2012) (showing tabular and graphical breakdowns of piracy attacks between January 2007 and Decem- 
2011 totaled more than 400 each year-exceeding by more than half of the total reported attacks in 2007. ${ }^{88}$ These numbers do not mean that passive defensive measures and the naval patrols had no antipiracy effect. According to the Lang Report, naval forces "thwarted 126 attacks in 2008, 176 in 2009 and 127 in 2010." 89 In addition, the IMB credits the navies and the use of defensive measures with reducing the number of successful attacks Somali pirates staged during 2011. ${ }^{90}$ Nonetheless, as another report laments, although the navies contributed to a decrease in the number of the successful hijackings, they did not "contain the growth in the overall number of attacks and the area in which pirates can operate."91

In fact, some commentators suggest that the vastness of the area in which Somali pirates operate means naval patrols could never keep every ship safe. ${ }^{92}$ According to the U.K. Major General Howes (Operation Commander of Atalanta), about "83 [ships] would be needed to provide response conditions of half an hour . . ..93 William Wechsler, the U.S. Deputy Assistant Secretary of Defense for Counternarcotics and Global Threats, offers the more pessimistic view that all the navies in the world could not protect the approximately 2.9 million nautical miles in which pirates may stage attacks. ${ }^{94}$ Because of budgetary pressures, however, there are reasons to suspect that states may provide fewer naval resources in the fight against piracy in upcoming years. ${ }^{95}$

Faced with this apparent "security gap" that left ships and their crews vulnerable to pirate attacks, ship owners argued for more

ber 2011 in different regions) [hereinafter ICC-IMB 2011 REPORT]. The International Maritime Bureau (IMB) includes in its annual report acts of piracy and acts of armed robbery against ships, as well as attempts of the same. Id. at 8 . The IMB's definition of piracy includes illegal acts of violence against a ship travelling on the high seas or any act of inciting the same. $I d$. at 3 . Its definition of armed robbery against ships includes acts of violence-or any act of inciting an act of violence-against a ship located "within a State's internal waters, archipelagic waters and territorial sea . . ." Id.

88. Id. at 5-6 (showing 263 actual and attempted attacks in 2007, as compared to 410 in 2009, 445 in 2010, and 439 in 2011).

89. Lang Report, supra note 7, para. 39.

90. ICC-IMB 2011 REPORT, supra note 87, at 20.

91. Foreign Affairs Committee 2012 Report, supra note 31, Summary; see also Lang Report, supra note 7, para. 39 (stating that between 2007 and 2010, the number of pirate attacks continued to grow despite the presence of naval forces).

92. David C. Ake, Defense Official: More Private Security Needed Aboard Ships to Combat Piracy, Nat'l Def. (June 16, 2011, 4:10 PM), http://www.nationaldefensemagazine.org/ blog/Lists/Posts $/$ Post.aspx?ID=447.

93. Foreign Affairs Committee 2012 Report, supra note 31, II 51.

94. Ake, supra note 92.

95. Economic Cost 2011, supra note 37, at 25. 
protection. ${ }^{96}$ They pleaded for states to allow them to hire private armed guards to accompany their crews as they travelled through pirate-infested waters. ${ }^{97}$ By about mid-2011, many states heeded these pleas and authorized the use of armed guards on board ships. ${ }^{98}$ Ship owners also appear to have embraced the use of private armed security in the fight against maritime piracy. ${ }^{99}$ Estimates indicate that the percentage of ships employing armed guards rose from approximately ten percent to fifty percent in 2011. ${ }^{100}$ Ship owners and operators spent more than $\$ 1$ billion for this private protection in 2012 alone. ${ }^{101}$

The good news is that since 2012 these various defensive tactics employed by states and ship owners seem to have helped significantly reduce the number of successful attacks. ${ }^{102}$ One often cited anecdote is that no ship carrying armed personnel has been successfully hijacked. ${ }^{103}$ Nevertheless, both the IMB and those who have participated in the naval counterpiracy patrols warn against complacency, arguing that Somali piracy remains a significant threat. ${ }^{104}$ According to one commentator, these recent gains are "fragile and reversible," particularly because the European Union

96. See, e.g., IMO, Piracy and Armed Robbery Against Ships: Recommendations to Governments for Preventing and Suppressing Piracy and Armed Robbery Against Ships, Annex II 4, 7, IMO Doc. MSC.1/Circ.1333 (June 26, 2009) (noting negative consequences that would result from self-arming of seafarers and from use of privately contracted armed security personnel).

97. Up until 2011, the maritime industry was generally opposed to using private armed guards on ships. See, e.g., id. Annex II 7 (cautioning that using private armed guards may lead to increased violence). Among other things, the industry cited concerns about the escalating violence if ships carried guns and the need to comply with transit state laws on weapons carriage. See, e.g., id. (noting concerns about having to comply with state laws on weapons carriage and the risks associated with having weapons around flammable or dangerous cargo and discussing the risks of escalating violence if weapons are allowed on board ships).

98. See Yvonne M. Dutton, Gunslingers on the High Seas: A Call for Regulation, 24 DukE J. Comp. \& INT'L L. 107, 108 (2013).

99. See generally Graduate Inst. of Int'l Dev. Studies, Small Arms Survey 2012: MovIng Targets 206 (2012) [hereinafter Small Arms Survey 2012]; see also Economic Cost 2011, supra note 37 , at 17 .

100. Small Arms Survey 2012, supra note 99; Economic Cost 2011, supra note 37, at 17 (explaining that although the generally accepted end-of-year percentage for 2011 is twenty-five percent, leading representatives from the shipping industry suggest the figure may be closer to fifty percent).

101. ECONOMic Cost 2012, supra note 4, at 20.

102. ICC-IMB 2011 REPORT, supra note 87, at 5-6, 20.

103. Small Arms Survey 2012, supra note 99, at 206.

104. See ICC-IMB 2011 RePORT, supra note 87, at 21; Chris Mgidu, EU Naval Force Warns of Piracy Threat Despite Reduction off Horn of Africa, HirraAn Online (Nov. 8, 2012), http:// hiiraan.com/news4/2012/Nov/26761/eu_naval_force_warns_of_piracy_threats_despite_ reduction_off_horn_of_africa.aspx. 
and NATO mandates expire at the end of 2014, and the cost of hiring private armed guards is substantial and perhaps not sustainable. ${ }^{105}$ Furthermore, as one U.S. admiral who has commanded naval patrols notes, Somali pirates have demonstrated their ability to adapt to the various defensive measures employed-they began operating further out to sea to avoid naval patrols and boarding ships at night to avoid ships' passive security measures. ${ }^{106}$ That same admiral stresses that pirates are in the business of making money and that they have found, and will continue to find, ways to overcome the defensive measures that stand between them and a successful hijacking. ${ }^{107}$

In sum, the fight against Somali piracy is not over. At present, the various combined defensive tactics have proved successful in the short term; Somali pirates staged fewer successful hijackings in 2012 than in either 2010 or 2011.108 At the same time, however, the evidence suggests that they have not abandoned their quest for the huge ransom payments that follow from a successful pirate attack. According to Donna Hopkins, Chair of the U.N. Contact Group on Piracy off the Coast of Somalia, pirates "still roam a huge part of the Indian Ocean as well as the Red Sea and the Gulf of Aden looking for vessels to hijack." ${ }^{109}$ Recent news reports support this conclusion. In May 2013, E.U. antipiracy naval forces found a skiff 320 nautical miles off the Somali coast with six men and equipment commonly related to piracy on board. ${ }^{110}$ In June 2013, E.U. antipiracy naval forces rescued fourteen Indian sailors whose cargo ship had been boarded by twelve armed pirates in the Gulf of Aden. ${ }^{111}$

The following Section considers the role that prosecutions have played in the world community's fight against Somali piracy.

105. What Happened to Somalia's Pirates?, Economist (May 19, 2013, 11:50 PM), http:// www.economist.com/blogs/economist-explains/2013/05/economist-explains-11 (quoting Jon Huggins, a director at the nongovernmental organization, Oceans Beyond Piracy).

106. See Admiral Warns Against Withdrawing Naval Support on Piracy, Mar. SEc. InT'L (Oct. 24, 2012), http://www.maritimesecurityinternational.net/readnews.php?ide=87.

107. See id.

108. See Pirate Trails, supra note 38 , at 43.

109. No Hijacking by Somali Pirates in Nearly a Year, MaritimeSecurity.Asia (May 5, 2013), http://maritimesecurity.asia/free-2/piracy-2/no-hijacking-by-somali-pirates-innearly-a-year-2.

110. Counter Piracy Commander Warns of Continuing Threat as EU Naval Force Warship Once Again Denies Suspect Pirates Freedom of the Seas, AllAfrica.com (May 14, 2013), http:// allafrica.com/stories/201305141190.html.

111. See EU Naval Warship Rescues 14 Indian Sailors After Hijack, XinHua News Agency (June 6, 2013, 5:55 PM), http://news.xinhuanet.com/english/world/2013-06/07/c_ 132436572.htm. 


\section{The Fight Against Somali Piracy: Prosecutions}

How has the world community thus far dealt with the pirates? One answer is that the world's navies release a great number of Somali pirates without prosecution and thus have been accused of following a "catch and release" policy. ${ }^{112}$ This means that pirates can roam the seas and threaten ships, yet face little risk of being held accountable for their crimes even if they are unfortunate enough to be captured "in the act" by the world's navies. Each of the Danish, British, Canadian, and U.S. navies reportedly has released suspected Somali pirates, including in situations where they had evidence of illegal activities, all because no state would agree to take them. ${ }^{113}$ According to the Lang Report, only about one-third of the pirates captured between 2008 and 2010 were prosecuted. ${ }^{114}$ The "release" rate worsened over time. By 2011, "more than 90 per cent of the pirates apprehended by States patrolling the seas [were to be] released without being prosecuted." 115 Not surprisingly, the capturing navies identified some of the pirates who were previously apprehended and released as repeat offenders. ${ }^{116}$

Nevertheless, as of December 2012, some twenty-two states either were holding for prosecution or had already tried approximately 1190 Somali pirates. ${ }^{117}$ These numbers, however, deserve a closer look. First, twenty-two states are only a small portion of the states that are authorized to exercise jurisdiction over acts of piracy. Piracy is a universal jurisdiction crime, meaning any state can prosecute without nexus to the offense (for example, despite the fact that none of its citizens was the victim of the attack). ${ }^{118}$ Addition-

112. Lang Report, supra note 7, paras. 14, 43 .

113. See Oliver Hawkins, What to Do with a Captured Pirate, BBC NEWS (Mar. 10, 2009, 10:49 AM), http://news.bbc.co.uk/2/hi/7932205.stm (describing the Danish navy's release of suspected Somali pirates who were armed and in possession of notes stating how they would split their piracy proceeds); Foreign Affairs Committee 2012 Report, supra note 31, at Ev. 43-44 (questioning of Mr. Henry Bellingham, Minister of Parliament, where interviewer pointed out that during a one-month period in 2010, Britain's navy released suspected pirates found holding hostages on board three different mother ships); Craig Whitlock, Navy Releases Accused Somali Pirates Held on Warship for Six Weeks, WASH. Post (May 28, 2010, 6:18 PM), http://www.washingtonpost.com/wp-dyn/content/article/2010/05/ 28/AR2010052804108.html (describing the U.S. Navy's release of ten suspected Somali pirates after no state agreed to take them for prosecution).

114. Lang Report, supra note 7, paras. 14, 42-43.

115. Id. para. 14.

116. Id.

117. Economic Cost 2012, supra note 4, at 28.

118. See Anthony J. Colangelo, The Legal Limits of Universal Jurisdiction, 47 VA. J. INT'L L. 149, 151 (2006); see also 4 William Blackstone, Commentaries on the Laws of England 
ally, most states are parties to the U.N. Convention on the Law of the Sea (UNCLOS) ${ }^{119}$ and the Convention for the Suppression of Unlawful Acts Against the Safety of Maritime Navigation (SUA Convention), ${ }^{120}$ both of which authorize and encourage nations to cooperate in prosecuting acts of maritime piracy. ${ }^{121}$

Second, only about ten percent of the pirates being prosecuted are under prosecution by European and other states whose navies frequently capture suspected pirates. $^{122}$ Western states have demonstrated a general reluctance to prosecute Somali pirates, particularly if the pirates have not harmed the state's own citizens. $^{123}$ Instead, those states have entered into agreements with Kenya, the Seychelles, and other African nations allowing them to transfer pirates for prosecution in exchange for monetary and

72 (1897); M. Cherif Bassiouni, Universal Jurisdiction for International Crimes: Historical Perspectives and Contemporary Practice, 42 VA. J. INT'L L. 81, 110-11 (2001).

119. United Nations Convention on the Law of the Sea arts. 100-08, 110, Dec. 10, 1982, 1833 U.N.T.S. 397 [hereinafter UNCLOS]. As of October 2013, 166 states were parties to the U.N. Convention on the Law of the Sea (UNCLOS). See Chronological Lists of Ratifications of, Accessions and Successions to the Convention and the Related Agreements, UnITED Nations Div. for Ocean Aff. \& L. Sea (Sept. 20, 2013), http://www.un.org/Depts/los/ reference_files/chronological_lists_of_ratifications.htm.

120. Convention for the Suppression of Unlawful Acts Against the Safety of Maritime Navigation, Mar. 10, 1988, 1678 U.N.T.S. 221 [hereinafter SUA Convention]. As of June 2013, 160 states were parties to the Convention for the Suppression of Unlawful Acts Against the Safety of Maritime Navigation (SUA Convention). Inventory of International Nonproliferation Organizations $\mathcal{E}$ Regimes, Center for Nonproliferation Stud. (July 16, 2012), http://cns.miis.edu/inventory/treaties.htm (follow "Convention for the Suppression of Unlawful Acts against the Safety of Maritime Navigation" hyperlink; then follow "Membership" hyperlink).

121. See UNCLOS, supra note 119, art. 105; SUA Convention, supra note 120, arts. 5-6.

122. See, e.g., Economic Cost 2012, supra note 4, at 28 (showing that of the 1190 pirates, 288 are being prosecuted by Kenya and Seychelles alone; about 127 are being prosecuted by Belgium, France, Germany, Italy, Japan, the Netherlands, Spain, and the United States); Eugene Kontorovich \& Steven Art, An Empirical Examination of Universal Jurisdiction for Piracy, 104 Am. J. INT'L L. 436, 445 (2010) (showing that the navies capturing pirates on the high seas during 2008 and 2009 typically transferred the pirates to Kenya for prosecution); U.N. Secretary-General, Report of the Secretary-General on Possible Options to Further the Aim of Prosecuting and Imprisoning Persons Responsible for Acts of Piracy and Armed Robbery at Sea off the Coast of Somalia, Including, in Particular, Options for Creating Special Domestic Chambers Possibly with International Components, a Regional Tribunal or an International Tribunal and Corresponding Imprisonment Arrangements, Taking into Account the Work of the Contact Group on Piracy off the Coast of Somalia, the Existing Practice in Establishing International and Mixed Tribunals, and the Time and Resources Necessary to Achieve and Sustain Substantive Results, II 19-23, U.N. Doc. S/2010/394 (July 26, 2010) (showing that of approximately seven hundred suspected pirates being held for prosecution as of May 2010, about ninety percent were being tried in African states).

123. See Yvonne M. Dutton, Maritime Piracy and the Impunity Gap: Insufficient National Laws or a Lack of Political Will?, 86 TuL. L. Rev. 1111, 1136-37 (2012) (describing various piracy prosecutions of Western states, all of which involve state citizens as victims of the attacks). 
other support. ${ }^{124}$ With support from the U.N. Office on Drugs and Crime (UNODC), Kenya has conducted eighteen trials involving 147 suspects. ${ }^{125}$ Similarly, the Seychelles is processing fourteen cases involving 118 suspects. ${ }^{126}$ Yet, as even these numbers indicate, Kenya and other African states cannot prosecute all of the pirates captured by patrolling navies. Moreover, as Lang noted, some states will not want to bear the whole burden of prosecuting pirates and likely will be more willing to do so if they see that Western states are also prosecuting cases. ${ }^{127}$

In short, although some pirates are being prosecuted, evidence also points to a culture of impunity whereby a great number of alleged pirates have been able to escape justice. This culture of impunity has reigned despite repeated calls to states to prosecute more pirates. The U.N. Security Council, for instance, has emphasized that the failure to prosecute pirates undermines antipiracy efforts and has accordingly called on states to criminalize piracy under their national laws and favorably consider trying pirates in their domestic courts. ${ }^{128}$ The Lang Report echoed the call for increased prosecutions of pirates, noting that bringing captured pirates to justice is a crucial component of an effective

124. Beginning in 2009, Kenya entered into agreements with various countries to try pirates captured by the world's navies. See, e.g., Council Decision 2009/293/CFSP, Acts Adopted Under Title V of the EU Treaty, art. 1, 2009 O.J. (L 79/47) 47 (EC) (concerning the exchange of letters between the European Union and the Government of Kenya on the conditions and modalities for the (1) transfer of persons suspected of having committed acts of piracy and detained by the E.U. led naval force (EUNAVFOR), and (2) the transfer of persons, who had seized property in the possession of EUNAVFOR, from EUNAVFOR to Kenya and their treatment after such transfer). Thereafter, Mauritius, the Seychelles, and Tanzania followed. See, e.g., Jean Paul Arouff, Mauritius Says Ready to Try, Imprison Pirates, Reuters (June 12, 2010, 4:58 AM), http://www.reuters.com/article/ idUSLDE65B021; Mariama Diallo, Nations Prove More Willing to Combat Piracy than Prosecuting Pirate Suspects, Vorce Am. (June 7, 2010), http://www.voanews.com/english/news/ africa/east/Nations-Prove-More-Willing-to-Combat-Piracy-than-Prosecuting-Pirate-Suspects $-95861284 . h t m l$ (stating that the Seychelles recently began prosecuting pirates, setting up a special court to hear some thirty-one cases); Daniel Richey, Mauritius to Try Accused Somali Pirates, Jurist (June 13, 2010, 2:37 PM), http://jurist.org/paperchase/2010/06/mauritiusto-try-accused-somali-pirates.php; Council Decision 2009/877/CFSP, Acts Adopted Under the EU Treaty, art. 1, 2009 O.J. (L 315) 35 (discussing the signing and provisional application of the exchange of letters between the European Union and the Republic of Seychelles on the conditions and modalities for the transfer of suspected pirates and armed robbers from EUNAVFOR to the Republic of Seychelles and for their treatment after such transfer).

125. See UNODC and Piracy, UNODC, http://www.unodc.org/easternafrica/en/piracy/ index.html (last visited Mar. 7, 2014).

126. Id.

127. Lang Report, supra note 7, paras. 72-75.

128. See, e.g., S.C. Res. 1918, paras. 1-2, U.N. Doc. S/RES/1918 (Apr. 27, 2010); S.C. Res. 1950, paras. 12-13, U.N. Doc. S/RES/1950 (Nov. 23, 2010). 
counterpiracy strategy. ${ }^{129}$ The maritime industry similarly has argued that increasing the very low prosecution rate of captured pirates would have an important deterrent effect and protect more innocent seafarers from the risk of being held hostage. ${ }^{130}$

The remainder of this Article considers whether and under what circumstances criminal sanctions can deter the kinds of individuals who thus far have been drawn to the big money and lavish lifestyles available to successful Somali pirates.

\section{The Deterrent Effect of Criminal Sanctions}

Deterrence theory predicts that the credible threat of punishment-by way of an arrest, trial, and sentence-will convince individuals not to commit crimes. ${ }^{131}$ Both specific and general deterrence are goals of this well-enforced penalty regime. ${ }^{132}$ The credible threat of sanctions should specifically deter those who have violated the law and suffered a penalty from choosing to commit future crimes. The threat should also generally deter individuals from turning to a life of crime to avoid the likelihood of punishment. ${ }^{133}$

The theory does not, however, predict that even a perfectly formulated legal-sanctions regime can deter all criminals or all criminal behaviors. In fact, even those who agree that a credible threat of sanctions can deter some crimes argue that it may not deter certain criminals, such as those who commit crimes of passion. ${ }^{134}$

129. Lang Report, supra note 7, paras. 46, 73-75.

130. Foreign Affairs Committee 2012 Report, supra note 31, I 75 (describing the maritime industry's criticism of the "catch and release" policies, particularly the United Kingdom's "failure to prosecute those caught red-handed in the act of piracy"). In that same report, the U.K. Foreign Affairs Committee considers objections by government actors who argue that pirates were released because of the absence of sufficient evidence to criminally convict them. Id. I 81. Yet, the report also concludes as follows:

$[\mathrm{N}]$ ot all claims made by the Government about the difficulty in securing evidence were wholly convincing: when pirates are observed in boats with guns, ladders and even hostages, it beggars belief that they cannot be prosecuted, assuming that states have the necessary laws in place and the will to do so. Id.

131. See, e.g., Paternoster, supra note 1, at 766.

132. Id.

133. See, e.g., id. at 767; David Wippman, Atrocities, Deterrence, and the Limits of International Justice, 23 Fordham InT'L L.J. 473, 476 (1999); Joan MacLeod Heminway, Hell Hath No Fury Like an Investor Scorned: Retribution, Deterrence, Restoration, and the Criminalization of Securities Fraud Under Rule 10b-5, 2 J. Bus. \& TECH. L. 3, 4 (2007).

134. Jeffrey Fagan, Death and Deterrence Redux: Science, Law and Causal Reasoning on Capital Punishment, 4 Ohio St. J. Crim. L. 255, 291 (2006) ("No one doubts that the criminal law, as well as other types of legal sanctions, have deterrent effects, but the evidence suggests that such effects may be confined to risk groups atypical of homicide offenders" who 
Others argue that the credible threat of sanctions can produce only so much of a deterrent effect. ${ }^{135}$ For example, some commentators argue that finely tuning the applicable penalties for particular offenses is likely a wasted effort. ${ }^{136}$ They suggest that individuals will not know which precise penalties will apply for certain acts; thus, there is no likely marginal deterrent effect in increasing penalties for some crimes. ${ }^{137}$ Proving empirically that deterrence theory works is also a problem because it requires showing that individuals who otherwise would have committed crimes did not do so due to the threat of sanctions. ${ }^{138}$ Nevertheless, deterrence is a primary goal of any criminal justice system. ${ }^{139}$ Moreover,

act out of passion). But see Joanna M. Shepherd, Murders of Passion, Execution Delays, and the Deterrence of Capital Punishment, 33 J. Legal Stud. 283, 284, 305-14 (2004) (producing empirical evidence suggesting that capital punishment does deter even crimes of passion).

135. Paul H. Robinson \& John M. Darley, The Role of Deterrence in the Formulation of Criminal Law Rules: At Its Worst When Doing Its Best, 91 GeO. L.J. 949, 954 (2003); see also Daniel S. Nagin, Criminal Deterrence Research at the Outset of the Twenty-First Century, 23 CRIME \& Just. 1, 3 (1998) (concluding that evidence for a substantial deterrent is much firmer than it was fifteen years ago, but that this conclusion is of limited value in formulating policy because it is not whether the criminal justice system in its totality prevents crime, "but whether a specific policy, grafted onto the existing structure, will materially add to the preventive effect").

136. See Robinson \& Darley, supra note 135, at 1001.

137. See id. at 950-51, 954-55 (explaining that a criminal justice system that punishes violators has a general effect of deterring potential offenders, but lawmakers are wrong to assume they can further modulate the deterrent effects via targeted and incremental changes to criminal laws); see also Nagin, supra note 135, at 3 (questioning "whether a specific policy, grafted onto the existing structure, will materially add to the preventive [deterrent] effect").

138. For example, Paternoster examined some empirical studies pointing to a decreased crime rate following the increased use of imprisonment. See Paternoster, supra note 1 , at $800-05$. The evidence supported a conclusion that "the threat of imprisonment does indeed act as a general deterrent and probably is responsible for some share" of the reduction in the crime rate. $I d$. at 802 . On the other hand, he suggested caution before making "more definitive conclusions about the deterrent effect of imprisonment" because of, among other things, the difficulty of definitively proving causation. Id.

139. See, e.g., Robinson \& Darley, supra note 135, at 950 (suggesting that crime deterrence has been a centerpiece of criminal law reform and conceding that a punishment regime deters, but taking issue with the idea that fine manipulations of the penalties for particular crimes will not always influence conduct and produce any additional deterrent effect); Steven N. Durlauf \& Daniel S. Nagin, Imprisonment and Crime: Can Both Be Reduced?, 10 Criminology \& Pub. Pol'y 13, 15 (2011) (stating that criminologists often take a contrary position to that of economists and argue that the threat of sanctions does not always deter, but suggesting that criminologists should not ignore that deterrence should be a goal of any sound crime-control policy); Pasternoster, supra note 1, at 777-78 (explaining that despite decades of being criticized by criminologists and others, deterrence theory was revived in the late 1960 s). 
there is a general consensus that "there likely is a deterrent effect to the workings of the criminal justice system . . . ."140

Deterrence theory emerges from the law and economics literature, as opposed to, for example, the literature of criminologists. ${ }^{141}$ Criminologists focus on the individuality of would-be criminals and the personal or environmental factors that might encourage a particular person to engage in crime. ${ }^{142}$ For instance, some individuals may be more likely to commit crimes because they have few job prospects or are poor. ${ }^{143}$ Criminologists thus argue that policy solutions aimed at deterring crime should be targeted and address the unique circumstances that might lead a given individual or group of individuals to commit crime. ${ }^{144}$ Instead of focusing only on legal-sanctions regimes, criminologists might suggest that policymakers improve educational opportunities or eliminate poverty so that some individuals will have fewer push factors leading them to view crime as beneficial. ${ }^{145}$

Economists advancing theories of deterrence, by contrast, argue that a well-enforced legal-sanctions regime can help dissuade society as a whole from committing crimes-even those individuals who may have greater reasons to be lured by a life of crime. ${ }^{146}$ They proceed from the premise that all would-be criminals are selfinterested, rational actors, who are able to and do respond to the potential costs and benefits of committing illegal acts. ${ }^{147}$ Rational actors wish to maximize their utility and will choose the action that

140. Pasternoster, supra note 1, at 766; see also Nagin, supra note 135, at 3 (explaining that the author now agrees with others that the criminal justice system, as an entire body, does "exert a very substantial deterrent effect").

141. See, e.g., Pasternoster, supra note 1, at 777-78. Gary Becker is the scholar who is typically credited with being the first "modern" writer to apply a rational-choice economic analysis to the study of criminal law. Id. at 778 (citing Gary S. Becker, Crime and Punishment: An Economic Approach, 76 J. Pol. Econ. 169 (1968)).

142. See, e.g., Patrick J. Keenan, The New Deterrence: Crime and Policy in the Age of Globalization, 91 IowA L. Rev. 505, 515-16 (2006).

143. Id. at 515 (stating that because criminologists are concerned with individual motivations for crime, one policy response they might propose would be to eliminate poverty in order to decrease the incentive for poor people to commit crime).

144. Id.

145. Id. (mentioning elimination of poverty and improvement of education as some policy responses to the existence of crime that criminologists might favor).

146. Id. at 516 (noting that the law and economics deterrence literature seeks to explain criminal behavior as a general matter, as opposed to the specific preferences of individuals).

147. Paternoster, supra note 1, at 782; see also Keenan, supra note 142, at 516 (suggesting that unlike criminologists who seek to explain the preferences of individual offenders, economists' approach to deterrence theory seeks to explain offense behavior more generally and seeks more general policy responses to address that behavior). 
will produce the greatest benefits over costs. ${ }^{148}$ Deterrence theory also assumes that no one particular individual or set of individuals is innately or specially compelled by virtue of some psychological or other "flaw" to commit crime; rather, all people are presumed both rational and capable of committing a crime when doing so would maximize individual utility. ${ }^{149}$ Although each rational individual may have some different and unique circumstances that will inform his decision, deterrence theory still suggests the general calculus remains the same: one will not commit a crime if the likely costs of the action exceed the likely benefits one can reap from it. ${ }^{150}$

In the cost-benefit calculation of engaging in a criminal activity, an obvious benefit from most types of criminal activity is the opportunity to gain "easy money." 151 One can also imagine that, in some cases, individuals may obtain psychological benefits from criminal activity-for instance, the feeling of being able to "outsmart the police" or the feeling of knowing one's act has furthered some political or other agenda. The cost side of the equation, however, is the primary focus of deterrence theory. Deterrence theorists argue that an increased threat of punishment from a well-enforced criminal justice system will increase the cost of anticipated criminal activity, thereby both generally and specifically deterring individuals from committing crimes. ${ }^{152}$

Scholars typically focus on two principal considerations that inform the calculation of costs associated with a well-enforced criminal justice system: the certainty of punishment and its likely severity. ${ }^{153}$ Certainty of punishment refers to the likelihood that an offender will be arrested and convicted. ${ }^{154}$ Severity of punishment refers to the sanction's punitive quality-for example, whether the offense is punished by a fine, a prison term, or the death penalty. ${ }^{155}$ The certainty and severity of potential punishment can be observed objectively from data showing how likely it is that those committing certain types of crimes are punished and the sentences

148. See Durlauf \& Nagin, supra note 139, at 17.

149. Paternoster, supra note 1 , at 782 .

150. See, e.g., Keenan, supra note 142, at 515, 518-19; Paternoster, supra note 1, at 782-83.

151. Paternoster, supra note 1 , at 783 .

152. Durlauf \& Nagin, supra note 139, at 16; Paternoster, supra note 1, at 783-84.

153. See Keenan, supra note 142, at 519; Julian Ku \& Jide Nzelibe, Do International Criminal Tribunals Deter or Exacerbate Humanitarian Atrocities?, 84 WASH. U. L. REv. 777, 792 (2006).

154. Durlauf \& Nagin, supra note 139, at 16; Ku \& Nzelibe, supra note 153, at 792.

155. See Durlauf \& Nagin, supra note 139, at 16; Ku \& Nzelibe, supra note 153, at 792. 
they receive. Yet many scholars argue that what should matter most for deterrence theory are perceptions about punishment. ${ }^{156}$ In other words, even if the likely punishment is objectively certain and severe, a rational individual has to know something about the law and prescribed punishment in order to be deterred from committing crime. ${ }^{157}$

What specific limitations of deterrence theory are relevant to the question of whether and under what circumstances criminal sanctions are likely to deter Somali piracy? This Article explores two such limitations below. First, deterrence theory assumes a rational actor, an assumption that may not always apply. ${ }^{158}$ Second, as other scholars have noted, the threat of formal legal sanctions may be more likely to produce a deterrent effect, or a greater deterrent effect, if legal sanctions are also accompanied by some potential informal social sanctions. ${ }^{159}$

\section{A. The Rational Actor Assumption}

Deterrence theory assumes rational actors will adjust their behavior because of the credible threat posed by a well-enforced legalsanctions regime. Nevertheless, not all actors are deterred by that threat because not all are necessarily rational. As Professors Robinson and Daley suggest, there may be a "host of conditions that interfere with the rational calculation of self-interest by potential offenders ...."160

For instance, some individuals may be "irrational" in that they have atypical risk profiles-they are willing to assume the risk of paying high costs for their behavior. The suicide bomber is one example of a type of criminals who is generally undeterred by the threat of sanctions. Indeed, he is willing to die in order to carry out his illegal activity. ${ }^{161}$ No doubt he also presumably perceives that he and others of like mind will gain great benefits as a result of his actions because he will further political goals by terrorizing

156. See, e.g., Pasternoster, supra note 1, at 780 (explaining the evolution of deterrence theory to account for perceptions of objective sanction threats).

157. See id.

158. Professors Robinson and Darley are two among many to raise this concern about deterrence theory. See, e.g., Robinson \& Darley, supra note 135, at 955-56.

159. See, e.g., $\mathrm{Ku} \&$ Nzelibe, supra note 153, at 792-96; Keenan, supra note 142, at 536-37.

160. Robinson \& Darley, supra note 135, at 955.

161. See, e.g., Ku \& Nzelibe, supra note 153, at 793 (referencing the suicide terrorist as one type of individual for whom criminal law sanctions are unlikely to have a deterrent effect). 
some population. At the same time, the suicide bomber would appear to be a person for whom the costs carry no weight. He commits his criminal act even though the penalty for his action, death, is both certain and severe.

Suicide bombers are not the only ones who demonstrate this type of "irrational" response to the threat of sanctions. Some scholars suggest that individuals who commit mass atrocities will be undeterred by a legal-sanctions regime even if they perceive that punishment is relatively certain. ${ }^{162}$ These actors may be irrational because of the unique social context in which they operate-a society where the state has helped manifest a community of hatred or where the state is constantly experiencing civil warfare. Like the suicide bomber, individuals in these circumstances may fanatically believe that their violent acts are necessary to achieve a desired aim, such as the elimination of all people of another clan or religion. ${ }^{163}$ In these types of cases, individuals may focus almost exclusively on the "benefits" of their violent acts. ${ }^{164}$

\section{B. The Role of Complementary Informal Social Sanctions}

Deterrence theory focuses on how the criminal justice system generally influences societal behavior on committing crimes. It predicts that the threat of arrest and the potential additional punishment that may follow in the event of a conviction can dissuade a rational individual from becoming a criminal. Scholars suggest, however, that the deterrent effect of formal legal sanctions increases when accompanied by the threat that the individual will suffer informal social sanctions if his community learns of his criminal activities. ${ }^{165}$ For example, the costs associated with being arrested are greater for individuals who function within a commu-

162. Pádraig McAuliffe, Suspended Disbelief? The Curious Endurance of the Deterrence Rationale in International Criminal Law, 10 N.Z. J. Pub. \& INT'L L. 227, 234, 236-39 (2012).

163. See id.

164. See id.

165. See Kirk R. Williams \& Richard Hawkins, Perceptual Research on General Deterrence: A Critical Review, 20 L. \& Soc'y Rev. 545, 561-62 (1986) (suggesting that one should view the stigma of arrest and the resulting loss of social standing as contributing to the deterrence effect of the credible threat of legal sanctions); Keenan, supra note 142, at 536 (evidence suggests that individuals consider the informal sanctions, such as shame and social censure, in addition to the legal sanctions that could flow from their conduct); Nagin, supra note 135, at 19-20 (describing the literature considering how the informal societal sanctions that can complement formal legal sanctions influence individual decisions on whether to engage in criminal activity); Franklin E. Zimring \& Gordon J. Hawkins, Deterrence: The Legal Threat in Crime Control 174 (1973) (suggesting that formal legal sanctions can set off societal reactions that can also aid in deterring criminal behavior). 
nity that may also shun them for being arrested-a community where criminal activity is relatively rare and thus stigmatizing. In such a community, in addition to facing jail time or other formal sanctions, an arrested individual may lose friendships, job opportunities, or social standing. ${ }^{166}$

A study by Professors Nagin and Klepper is helpful. They found that middle-class individuals were willing to evade taxes where the threatened legal sanction was only a civil monetary penalty. ${ }^{167}$ Because that sanction would be confidential, the sole risk to the individual was the loss of money. ${ }^{168}$ Where the threatened sanction was the potential to be publicly arrested and tried for tax evasion, those same individuals were unwilling to break the law. ${ }^{169}$ In this case, the threat of criminal legal sanctions would be an obvious deterrent. Additionally, the filing of criminal charges could expose these middle-class individuals to a host of social sanctions because they presumably operate within a conventional community where engaging in a criminal activity is considered morally unacceptable. ${ }^{170}$

On the other hand, for individuals who function within a community where crime is rampant or common, complementary informal social sanctions may be absent from the deterrence calculus. These individuals may face no real social stigma should they be publicly exposed as a criminal. ${ }^{171}$ In some communities, being known as a criminal may even have a reputation-enhancing effect. ${ }^{172}$ This general point about the absence of informal social sanctions is often made when discussing some of the difficulties of deterring serious international crimes, such as genocide or crimes against humanity. Because these types of crimes are committed in societies where everyone may seemingly belong to a warring or violent faction, individuals may lose their ability to distinguish right from wrong or legal from illegal. Moral norms may even compel

166. Williams \& Hawkins, supra note 165, at 563-66 (discussing how the potential for being stigmatized and losing friends as a result of arrest for engaging in criminal activity contributes to the general deterrence effect).

167. Nagin, supra note 135, at 20-21 (describing the Nagin and Klepper tax evasion study).

168. Id.

169. Id.

170. Id.

171. See Dan M. Kahan, Social Influence, Social Meaning, and Deterrence, 83 VA. L. Rev. 349, 350 (1997); see also Nagin, supra note 135, at 21 (emphasizing that for an event to be stigmatizing, it would have to be relatively uncommon within the community).

172. Kahan, supra note 171 , at 350 . 
committing the crime, whereas refusing to commit it may appear to be the socially deviant behavior. ${ }^{173}$

\section{Assessing the Deterrence Theory in the Context of Somali Piracy}

As noted above, various interested constituencies have long advocated that prosecuting, rather than releasing, captured pirates is an important component of any effective long-term solution to the problem of Somali piracy. That prosecutions will deter future acts of piracy seems almost assumed. This Article, however, seeks to go beyond assumptions by specifically analyzing how and under what circumstances would-be Somali pirates might be deterred by a rigorous, well-enforced, and strict credible threat of punishment. It does so by exploring the various aspects of deterrence theory in the context of Somali piracy. It considers (1) whether Somali pirates are the types of rational actors who can be deterred by the threat of legal sanctions; (2) how the current legal-sanctions regime affects a would-be Somali pirate's decision to commit criminal acts and whether it poses enough of a credible threat to produce a deterrent effect; and (3) whether any complementary informal sanctioning regime exists to aid in further deterring individuals from choosing to become Somali pirates.

\section{A. Somali Pirates as Rational Actors}

As an initial matter, evidence tends to suggest that Somali pirates on the whole are rational actors with a relatively normal risk profile. They can be distinguished easily from the suicide bomber who accepts a hundred percent risk of death in order to fulfill his mission of spreading a political message through acts of terrorism. All criminals who intend to commit violent felonies must face some risk that their victims will fight back violently or that law enforcement may use deadly force to stop them. Indeed, about five percent of pirates who encountered naval forces were killed during the period from March 25, 2010, to April 26, 2011.174 On the other hand, five percent is not one hundred percent. Nor is the five percent risk of death significantly different from that faced by others engaged in criminal activities. ${ }^{175}$

173. See McAuliffe, supra note 162, at 238.

174. See 2013 World Bank Report, supra note 4, at 129 (reporting on statistics about pirate fatality rates compiled by Bruxelles).

175. See id. (referencing a study that found a seven percent fatality rate for a street gang that dealt drugs in New York). 
Even though they risk death, evidence also shows that pirates act rationally to maximize the likelihood of a successful attack and minimize the likelihood of being caught or killed. They maximize the likelihood of a successful hijacking by primarily targeting slow ships that have low maneuverability. ${ }^{176}$ Somali pirates minimize their risk of death by curtailing their activities during monsoon seasons when the seas are most dangerous. ${ }^{177}$ They move their activities further out to sea to decrease their chances of being thwarted by the roving naval patrols. ${ }^{178}$ Somali pirates also tend not to engage with ships visibly protected by armed guards. ${ }^{179}$ Moreover, if they are caught by the world's navies, Somali pirates tend to throw their weapons and other gear overboard to minimize the chance of successful prosecution for engaging in or attempting an act of piracy. ${ }^{180}$

Finally, evidence also indicates that Somali pirates are not "fanatics" driven by some ingrained or instilled hatred or some quest to further a political agenda. For some years, Somali pirates have tried to justify their actions by claiming that they were forced to turn to piracy because of illegal fishing. ${ }^{181}$ That claim, however, is generally discredited. ${ }^{182}$ According to a recent World Bank report, "fisheries were never a leading economic activity in Somalia

176. Id. at 90 .

177. Bergen Risk Solutions, Somali Piracy and the Monsoon Seasons: A Study of Seasonal Variations in Attack Patterns 8 (2010) (reporting that Somali pirates tended to avoid the Indian Ocean entirely during monsoon seasons because of strong winds and high waves); Piracy to Heat Up as Monsoon Season Comes to End, MaritimeSecurity.Asia (Oct. 6, 2011), http://maritimesecurity.asia/free-2/piracy-2/piracy-to-heat-up-as-monsoonseason-comes-to-end (reporting on the increased risk of Somali pirate attacks as monsoon seasons come to an end).

178. See, e.g., Foreign Affairs Committee 2012 Report, supra note 31, I 51 (stating that as naval operations have become more successful at ensuring ships safe passage through the Gulf of Aden corridor, pirates have expanded their activities into the larger Indian Ocean); ICC-IMB 2011 RePort, supra note 87, at 20 (stating that Somali pirates were increasingly targeting ships travelling in the Red Sea and the wider Indian Ocean where naval patrols were not available).

179. See, e.g., Small Arms Survey 2012, supra note 99, at 206; Ake, supra note 92 (referencing the often cited anecdote which suggests that no ship carrying private armed guards has been successfully hijacked by Somali pirates).

180. See, e.g., Luis Martinez, Somali Pirates Attack Spanish Warship and Lose, ABC News (Jan. 12, 2012, 8:15 PM), http://abcnews.go.com/blogs/politics/2012/01/somali-piratesattack-spanish-warship-and-lose (reporting that Somali pirates often dump their weapons to avoid being detained if caught); German Navy Intercepts Somali Pirates, Am.'s N. Shore J. (Oct. 3, 2011, 11:10 PM), http://northshorejournal.org/german-navy-intercepts-somalipirates (describing a situation where Somali pirates were intercepted by a naval patrol and began throwing weapons overboard).

181. See supra notes 26-30 and accompanying text.

182. See supra notes 24-28 and accompanying text. 
...."183 Instead, Somali piracy has adversely affected the fishing industry in the region because the fishing vessels try to avoid the possibility of being attacked. ${ }^{184}$ In short, the general consensus is that Somali pirates are maximally driven by a profit motive: a quest to share in the increasingly huge ransoms that are paid to release ships and crews from being held hostage. ${ }^{185}$

\section{B. Somali Piracy and the Cost/Benefit Calculation}

Even if Somali pirates are rational actors, deterrence theory predicts they will be dissuaded from a life of crime only if the costs of criminal behavior outweigh the benefits. The main costs on which the theory focuses are those derived from a legal-sanctions regime. The regime must produce a sufficiently credible threat of punishment so it convinces potential offenders that crime is not worth the punishment. ${ }^{186}$ The sanctions must be objectively credible. Additionally, Somali pirates must have some understanding of the nature of that sanctioning regime and whether it is likely to impose certain and severe punishment on those who hijack ships and hold crew members hostage. ${ }^{187}$ This Section addresses several considerations relevant to how Somali pirates might calculate costs and benefits in view of the current legal-sanctions regime for punishing acts of piracy.

Initially, one might ask whether a Somali pirate could ever be sufficiently threatened by a legal-sanctions regime given the lack of opportunity in Somalia for individuals to earn anything close to a living wage. After all, Somalia is a very poor country, and many individuals lack viable options for employment. ${ }^{188}$ Nevertheless, there are still reasons to conclude that poverty alone does not mean a credible threat of sanctions could not deter low-income individuals from becoming criminals.

Although many people throughout the world may be relatively poor, not all commit crime. In addition, as Professor Hansen points out, not even all people in Somalia become pirates. ${ }^{189}$ Rather, piracy is prevalent only in parts of Somalia despite wide-

183. 2013 WORLD BANK REPORT, supra note 4, at 57 (reporting that this interpretation has now become a legitimizing narrative).

184. Id.

185. See supra notes $33-45$ and accompanying text.

186. See supra notes 33-45 and accompanying text.

187. See discussion supra Part III.

188. Martin, supra note 10.

189. Hansen, supra note 5, at 13. 
spread poverty throughout the country. ${ }^{190}$ Moreover, some of the regions where piracy is prevalent, such as Puntland, ${ }^{191}$ are relatively well-off economically as compared to other areas of Somalia. ${ }^{192}$ Even though being poor might provide an added incentive to seek "easy money" through a life of crime, poverty does not necessarily mean that individuals in Somalia have no real choice but to become pirates. There is ample evidence to suggest that many pirates do not seek only to elevate themselves above the poverty level. They gamble for the opportunity to obtain big houses, fast cars, drugs, and the feeling of being "rich."193

Nevertheless, what is the nature of the current gamble? What are the potential costs against which Somali pirates must weigh the chance to earn the riches that can be theirs from a hefty ransom payment? According to the deterrence theory, the cost calculation requires the rational individual to consider both the certainty and severity of punishment. ${ }^{194}$ As discussed below, this Article concludes that the present legal-sanctions regime is probably insufficient at least for the certainty of punishment to sufficiently deter many would-be Somali pirates. This Article concludes that the regime could make punishment more certain.

\section{Certainty of Punishment}

There are numerous reasons the present legal-sanctions regime for maritime piracy is not sufficiently enforced to send a credible threat to would-be Somali pirates that they are to be punished for their illegal acts. ${ }^{195}$ First, the international community more commonly releases captured pirates rather than prosecutes those pirates in their own domestic jurisdictions. ${ }^{196}$ Yet, piracy is a universal crime that all states may prosecute without having any nexus

190. Id.

191. See Pirate Trails, supra note 38, at 23 n.1.

192. Hansen, supra note 5 , at 13.

193. See supra notes 33-45 and accompanying text.

194. See discussion supra Part III.A (discussing deterrence theory).

195. Both the objective likelihood of sanctions and the perception that sanctions will be forthcoming are relevant to this inquiry about the certainty of punishment; the objective properties of punishment are important because they influence individual perceptions about the likelihood of punishment. Paternoster, supra note 1, at 780. In the case of Somali piracy, more regular prosecution as opposed to release should raise the perception that sanctions will be forthcoming.

196. See supra notes 93-95 and accompanying text; see also Kontorovich \& Art, supra note 122, at 444 (reporting that less than 1.5 percent of the 1158 reported piracy attacks in international waters between 1998 and 2009 resulted in a universal jurisdiction prosecution). 
to the offense. ${ }^{197}$ Because the international community has chosen to prosecute only a small percentage of captured Somali pirates, pirates can greatly discount the certainty of punishment. This is the very cost factor that a number of scholars have suggested as the most important for certainty and severity of punishment. ${ }^{198}$

Indeed, consider what message the ten percent rate of prosecution referenced in the Lang Report sends about the certainty of punishment. ${ }^{199}$ While poverty alone may not drive an ordinary Somali male to consider piracy, a ten percent prosecution rate could cause some to decide that the benefits of piracy exceed its probable costs. After all, some economists estimate that "the average pirate could earn between $[\$] 33,726$ and $[\$] 78,840$ a year, depending on the ransom paid." 200 This remuneration is obviously well above what the ordinary Somali male could otherwise earn. If the risk of imprisonment is low-as it is presently-the message is that crime may actually pay. ${ }^{201}$ Many who have been caught have been identified as repeat offenders, signifying that some pirates have internalized the message that maritime piracy is an activity for which they may not be punished. ${ }^{202}$

Second, Somali pirates essentially receive the same message about the certainty of punishment domestically: they are not likely to be subjected to legal sanctions. Much evidence indicates that government officials in the areas where piracy is most prevalent have been complicit in helping the profitable criminal activity thrive. Many Somali pirate bosses emerged in Central Somalia after escalating conflicts led to a fragmentation of power and a decline of local institutions capable to enforce the rule of law. ${ }^{203}$ In both Puntland and Central Somalia, where most hijacked ships

197. See Miriam Cohen, The Analogy Between Piracy and Human Trafficking: A Theoretical Framework for the Application of Universal Jurisdiction, 16 Buff. Hum. RTs. L. Rev. 201, 201 (2010) (observing that the doctrine of universal jurisdiction was developed to allow all states to prosecute piracy that occurred on the high seas whether or not they had a nexus to the offense).

198. See, e.g., Durlauf \& Nagin, supra note 139, at 17; Dawn L. Rothe \& Christopher W. Mullins, Beyond the Juristic Orientation of International Criminal Justice: The Relevance of Criminological Insight to International Criminal Law and Its Control: A Commentary, 10 INT'L CRIM. L. Rev. 97, 104, 110 (2010); Linda S. Beres \& Thomas D. Griffith, Habitual Offender Statutes and Criminal Deterrence, 34 Conn. L. Rev. 55, 59 (2001).

199. See Lang Report, supra note 7, para. 14.

200. Geopolicity, supra note 33, at 12.

201. Foreign Affairs Committee 2012 Report, supra note 31, at Summary (stating that "the risk to pirates of serious consequences is still too low to outweigh the lucrative rewards from piracy").

202. See Lang Report, supra note 7, para. 14.

203. 2013 World Bank Report, supra note 4, at 149-50; Hansen, supra note 5, at 57. 
are anchored, pirates apparently use a mix of financial incentives and physical threats to co-opt government officials, clan leaders, businesspeople, and Al-Shabaab militants. ${ }^{204}$ Indeed, both of Puntland's presidents, Abdullahi Yusuf Ahmed and Farole, have been accused of accepting money from pirates. ${ }^{205}$ Puntland's police and coast guard forces still allegedly include former pirates. ${ }^{206}$ Moreover, commentators also argue that most pirates either escape or are protected against arrest by clan members or corrupt police in Puntland. ${ }^{207}$ In sum, within Somalia, the message is that Somali pirates can continue with their illegal activities and face little threat of punishment.

Of course, potential offenders of domestic laws may nevertheless conclude that the likelihood of punishment for their crimes is low enough that committing an offense is worth the gamble. Domestic law enforcement bodies are not always able to capture criminals in the act or after the fact, and clearance rates for different types of crimes can vary. ${ }^{208}$ According to statistics maintained by the U.S. Federal Bureau of Investigation, law enforcement agencies in the United States cleared approximately sixty-six percent of murder offenses and about fifty-nine percent of aggravated assault offenses in 2011.209 For property offenses, however, law enforcement was less successful, clearing about twenty-eight percent of robberies and twelve percent of burglaries. ${ }^{210}$ Yet these statistics speak to

204. See Hansen, supra note 5, at 57-58 (reporting on the bribes paid to officials in Puntland); see also 2013 WORLD BANK REPORT, supra note 4, at 143. Al-Shabaab is a jihadist group based in Somalia that pledged allegiance to al-Qaeda in 2012. See Al-Shabaab Joining Al Qaeda, Militant Group Says, CNN (Feb. 10, 2012), http://www.cnn.com/2012/02/09/ world/africa/somalia-shabaab-qaeda.

205. 2013 World BANK RePORT, supra note 4, at 149 (reporting that President Ahmed has been accused of accepting money from pirates); HANSEN, supra note 5, at 57 (reporting that President Farole has been accused of being in league with the pirates).

206. Hansen, supra note 5 , at 58 .

207. Id. at 40; see also Eugene Kontorovich, The Penalties for Piracy: An Empirical Study of National Prosecution of International Crime 10 (Nw. Univ. Sch. of Law Scholarly Commons, Paper No. 211, 2012), available at http://papers.ssrn.com/sol3/papers.cfm?abstract_id $=2103661$ (stating that although local government officials in Somalia have reported some piracy convictions, details are absent and there are questions about whether sentences are being served).

208. See, e.g., Crime in the United States 2011, Fed. Bureau of Investigation, http:// www.fbi.gov/about-us/cjis/ucr/crime-in-the-u.s/2011/crime-in-the-u.s.-2011/clearances (last visited Mar. 7, 2014) (defining "clearance" as meaning that (1) at least one person participating in the offense has been arrested, charged, and transferred for prosecution, or (2) the case was solved, but it was closed for exceptional reasons, such as the death of the suspect).

209. Id.

210. Id. Statistics on clearance rates for crime in Canada during 2010 are similar. For violent crimes, the clearance rate was about seventy-two percent. For property crimes, it 
only one aspect of certainty: the possibility that one may never be caught, as opposed to the possibility that one will be prosecuted even if caught. In the United States, evidence indicates that the great majority of suspects who are arrested and turned over to prosecuting authorities are thereafter successfully prosecuted.211 The world community, however, has sent Somali pirates the message that even if the world's navies catch them in the act, they face only a tiny probability of prosecution. There is little hope that deterrence can operate effectively where the threat of prosecution is miniscule.

The fact that institutions within Somalia may lack either the ability or willingness to prosecute a sufficient number of pirates only increases the need for the international community to make piracy prosecutions a priority. Nonetheless, the international community may object that a strategy aimed at increasing prosecutions is costly in terms of both money and resource allocation. Reports indicate that states spent approximately $\$ 8.8$ million to try 104 alleged pirates in 2012.212 The United Nations and member states also provided funding to Kenya and the Seychelles to conduct piracy trials. ${ }^{213}$ The cost of trying piracy suspects is greater in some states than in others: the seven trials in Europe cost over $\$ 1$ million each on average; trials in North America averaged about $\$ 300,000$ each; and trials in Africa cost on average less than $\$ 300 .{ }^{214}$ An international commitment to prosecute a greater percentage of captured pirates would similarly cause total yearly prosecution costs to rise.

Cost, however, seems a poor reason to reject an antipiracy strategy that has the potential benefit of stopping Somalis from even considering piracy as a career choice. Prosecuting individuals who commit crimes costs money. States nevertheless spend substantial sums domestically on enforcing criminal laws to send a strong deterrent message that crime will not pay. For example, the U.S. federal government spent approximately $\$ 54$ billion on "the administration of justice" during 2010.215 The total expenditure

was twenty-four percent. Tina Hotton Mahony \& John Turner, Police-Reported Clearance Rates in Canada, 2010, Gov'т Canada (July 25, 2013), http://www.statcan.gc.ca/pub/85002-x/2012001/article/11647-eng.htm.

211. See sources cited supra note 9 .

212. EсONOMic Cost 2012, supra note 4, at 28-29.

213. Id. at 27-28.

214. Id. at 28-29.

215. See Office of Mgmt. \& Budget, Fiscal Year 2014: Historical Tables, Budget of THE U.S. Government 77 (2013), available at http://www.whitehouse.gov/sites/default/ files/omb/budget/fy2014/assets/hist.pdf. Note also that: 
for the Canadian criminal justice system during 2012 was approximately C $\$ 20.3$ billion. ${ }^{216}$ Australia spent about AUS $\$ 12.5$ billion on criminal justice. ${ }^{217}$ California alone allocated approximately $\$ 9.8$ billion for judicial and criminal justice programs for the fiscal year 2012-2013.218

In reality, all strategies aimed at solving the problem of maritime piracy are costly. The naval patrols cost upward of $\$ 1$ billion per year to maintain and require states to commit their equipment and personnel to the efforts. ${ }^{219}$ In 2012, the shipping industry spent about $\$ 1$ billion paying armed security guards to protect their ships and crews from pirate attacks. ${ }^{220}$ These efforts only hope to contain piracy. The goal of prosecutions is much more far reaching: to deter crime generally and specifically by sending a message that criminal behavior will produce costly consequences. Even if prosecuting pirates is costly, the money is well spent if it aids deterring future hijackings by sending a message to Somali pirates that crime will not pay.

\section{Severity of Punishment}

The present legal-sanctions regime is less lacking with respect to the severity of sanctions for piracy offenses. When pirates are prosecuted, they can face lengthy prison sentences, including life sentences. ${ }^{221}$ They may also face the death penalty in some coun-

The Administration of Justice function consists of federal law enforcement programs, litigation and judicial activities, correctional operations, and state and local justice assistance. Agencies within this function include: the Federal Bureau of Investigation; the Drug Enforcement Administration; Border and Transportation Security; the Bureau of Alcohol, Tobacco, Firearms and Explosives; the United States Attorneys; legal divisions within the Department of Justice; the Legal Services Corporation; the federal Judiciary; and the Federal Bureau of Prisons. This function includes several components of the Department of Homeland Security.

See Budget Functions, House Representatives Comm. on Budget, http:/ /budget.house.gov/ budgetprocess/budgetfunctions.htm (last visited Mar. 7, 2014).

216. Rod Story \& Tolga R. Yalkin, Office of the Parliamentary Budget Officer, Expenditure Analysis of Criminal Justice in Canada 14 (2013), available at http:// www.pbo-dpb.gc.ca/files/files/Crime_Cost_EN.pdf.

217. Criminal Justice Resources, Australian Inst. Criminology (June 4, 2013), http:// www.aic.gov.au/publications/current\%20series/facts/1-20/2012/7_resources.html.

218. Mac Taylor, Legislative Analyst's Office (LAO), The 2012-13 Budget: CaliFORnia Spending Plan 46 (2012), available at http://www.lao.ca.gov/reports/2012/bud/ spending_plan/spending-plan-091312.pdf.

219. Economic Cost 2012, supra note 4, at 2.

220. Id. at 20 .

221. See Kontorovich, supra note 207, at 11 (finding that the average sentence for pirates convicted in foreign courts is about sixteen years). 
tries. ${ }^{222}$ Reports indicate that a court in Yemen imposed the death sentence on several Somali pirates. ${ }^{223}$ The United States filed an intention to seek the death penalty for three Somali pirates charged with murdering four Americans whose yacht the pirates hijacked.224 Those pirates ultimately were given life sentences ${ }^{225}$ still a very severe punishment. Whether Somali pirates are aware of these sentences is a question to which no unequivocal answer is possible. Answering it would require information about the state of knowledge among various individuals in Somalia, a task that is beyond the scope of this Article. Worth noting, though, is that Somali news outlets in the English language have reported on the trials and sentences of Somali pirates in foreign jurisdictions. ${ }^{226}$

One complicating factor for any severity calculation is that the penalty a Somali pirate receives is dependent not only on the nature of the precise crimes he committed (for example, whether he acted as a guard or murdered a hostage) but also on the sanctioning regime of the prosecuting state and the penalties it assigns to different crimes. Professor Kontorovich reports that Somali pirates tried in foreign jurisdictions have received sentences ranging from four years to life in prison, and he concludes that some of the sentencing differential is due solely to the systemic differences

222. Marco 't Hoen, Six Somali Pirates Sentenced to Death in Yemen, Еpoch Times (May 19, 2010), http://www.theepochtimes.com/n2/world/six-somali-pirates-sentenced-to-deathin-yemen-35778.html.

223. Id.

224. U.S. to Seek Death Penalty in Somali Yacht Hijacking, USA Today (May 1, 2012, 8:12 PM), http://usatoday30.usatoday.com/news/nation/story/2012-05-01/somali-piratesprosecution/54671734/1.

225. Life in Prison for Somali Pirates Who Murdered Four Americans, MARIneLink.com (Aug. 7, 2013), http://www.marinelink.com/news/americans-murdered357365.aspx.

226. See, e.g., Basil Katz, Somali Pirate Handed 33-Year Sentence by U.S. Court, SomaliLAnd Times (Feb. 19, 2011), http://www.somalilandtimes.net/sl/2011/473/19.shtml (reporting on the sentencing of one pirate involved in a 2009 hijacking of the Maersk Alabama); Hassan Ali, Five Somalis Sentenced to Life in Piracy Case, SomalilandPress (Mar. 14, 2011), http:/ /somalilandpress.com/five-somalis-sentenced-to-life-in-piracy-case-20968 (reporting on the sentences imposed by a U.S. District Court); Somalia: Five Somali Pirates Sentenced to Jail in France, Garoweonline (Dec. 1, 2011, 7:34 AM), http://www.garoweonline.com/artman2/ publish/Somalia_27/Five_Somali_pirates_sentenced_to_jail_in_France_printer.shtml (reporting on Somali pirates who were sentenced between four and eight years by a French court); Somalia: Somali Pirate Sentenced to Life in US, Garoweonline (Mar. 31, 2012, 6:23 AM), http://www.garoweonline.com/artman2/publish/Somalia_27/Somalia_Somali_ pirate_sentenced_to_life_in_US_printer.shtml (reporting on Somali pirate sentenced to life by a U.S. court); Highest-Ranking Somali Pirate in U.S. Custody Loses Appeal to Overturn 12 Life Sentences for Killing 4 American Tourists, WARDheER News (July 13, 2013), http:// www.wardheernews.com/highest-ranking-somali-pirate-in-u-s-custody-loses-appeal-to-over turn-12-life-sentences-for-killing-4-american-tourists (reporting on the refusal to overturn one Somali pirate's life sentence prison term). 
in the punitive approach of the various fora. ${ }^{227}$ The fact that Somali pirates who commit the same types of criminal activity might be exposed to disparate sentences based on the location of their prosecution is not ideal from a fairness perspective. Nor is such sentencing inconsistency optimal in terms of deterrence theory because it means that individuals are less able to predict the severity of the sanctions they may face upon successful prosecution. On the other hand, individuals cannot predict with certainty the sentence they will receive for committing a crime even in a domestic context. ${ }^{228}$

Although the international context of piracy prosecutions means that pirates can face different maximum sentences for their crimes, at least some of those sentences are severe enough that they should produce a deterrent effect. Moreover, there is evidence suggesting that a credible threat of severe sanctions can deter Somali pirates. Consider that Somali piracy came to a virtual standstill for several months between 2006 and 2007 when the Islamic Courts Union (ICU) ${ }^{229}$ was able to control the areas where piracy was most prevalent. ${ }^{230}$ The ICU imposed Sharia law $^{231}$ and declared that piracy

227. See Kontorovich, supra note 207, at 13-14.

228. There are many reasons why individuals may not be able to predict in advance with certainty what punishment they will receive for a particular crime, including that prosecutors often have discretion regarding what charges to file and judges often have discretion to sentence offenders within some range of minimum and maximum penalties. See, e.g., Ely Aharonson, Determinate Sentencing and American Exceptionalism: The Underpinnings and Effects of Cross-National Differences in the Regulation of Sentencing Discretion, 76 L. \& CoNTEMP. Probs. 161, 168-69 (2013) (describing how prosecutors are able to influence sentencing outcomes in the United States even where certain crimes require a mandatory minimum sentence because of their ability to make charging decisions). The availability of parole and other early release programs can also make it difficult to predict what sentences different defendants who commit the same type of crime will actually serve. $I d$. at 173-74 (generally describing early release programs in the United States and other countries).

229. The Islamic Courts Union (ICU) was a group of Sharia courts that formed a rival administration to the Transitional Federal Government (TFG) of Somalia. See The Supreme Islamic Courts Union (ICU), GLOBALSECURITY.ORG, http://www.globalsecurity.org/military/ world/para/icu.htm (last visited Mar. 7, 2014). They ruled from May 2006 until early 2007 when they were ousted by an offensive, which included TFG forces and the Ethiopian military. Id. Sharia law is the law of Islam that governs in most Muslim states. It is derived from the Quran and the teachings of the prophet Muhammad and covers a variety of subjects. See Toni Johnson \& Lauren Vriens, Islam: Governing Under Shariah, Council on FOREIGN ReL. (Jan. 9, 2013) http://www.cfr.org/religion/islam-governing-under-shariah/ p8034.

230. Hansen, supra note 5, at 27; 2013 World Bank Report, supra note 4, at 160; see also Colin Freeman \& Justin Stares, Pirates Fear the Lash of Sharia Law, Telegraph (Oct. 15, 2006, 12:01 AM), http://www.telegraph.co.uk/news/worldnews/1531507/Pirates-fear-thelash-of-sharia-law.html (stating that the ICU had virtually wiped out piracy with the threat of tough punishments).

231. See supra note 229 for discussion of Sharia law. 
was an offense against Islam that would be harshly punished. ${ }^{232}$ To signal just how harsh such punishments would be, the ICU staged public executions of convicted murderers. ${ }^{233}$ Piracy became virtually nonexistent shortly after that display-an outcome that speaks to the deterrent effect severe sanctions can have on Somali piracy (although this Article is not advocating the public execution of pirates).234 It also lends support to the conclusion above that Somali pirates are rational individuals, even if they may have relatively few other attractive options for earning a living wage. After all, the crimes stopped.

Finally, one additional consideration is whether and how the potential to apply for asylum might factor into a Somali pirate's calculations about the likely severity of any punishment. One reason Western nations apparently have been reluctant to use universal jurisdiction to try maritime piracy cases on their home soil is because they fear potential asylum claims. ${ }^{235}$ Yet there is little reason to believe that this potential "benefit" of bringing a claim for asylum would be sufficient to convince an otherwise rational actor to discount a credible threat of certain and severe punishment. First, the very fact of a potential life or death sentence should convince most rational actors that the uncertain chance of obtaining asylum is not worth it. Second, if all states actually demonstrated their willingness to prosecute pirates, then pirates would not know which state would be prosecuting them. As a result, Somali pirates also could not determine in advance whether they would be tried by a state that would be more or less likely to grant them asylum. In some countries, like the United States, those who commit serious crimes cannot qualify for asylum. ${ }^{236}$ Moreover, the Counter Piracy Programme of the UNODC has been working with Somalia to provide funding for prisons so Somali pirates convicted in other nations can serve their sentences in the home countries. ${ }^{237}$ In fact,

232. Hansen, supra note 5, at 27; Freeman \& Stares, supra note 230.

233. Freeman \& Stares, supra note 230.

234. The idea that harsh punishments would deter piracy is not new. Apparently, that same tactic was used to put an end to the so-called "Golden Age of Piracy," which lasted from 1690 to 1730. See Angus Konstam \& Roger Michael Kean, Pirates: Predators of THE SEAs 179 (2007). Piracy was punishable by death and mass executions were used to demonstrate to pirates the near certainty of a painful and gruesome death. $I d$.

235. See Yvonne M. Dutton, Pirates and Impunity: Is the Threat of Asylum Claims a Reason to Allow Pirates to Escape Justice?, 34 Fordham Int'L L.J. 236, 239-40 (2011).

236. Id. at 284 (concluding based on an analysis of U.S. law that most Somali pirates would be unlikely to qualify for asylum in the United States).

237. See UNODC and Piracy, supra note 125; see also UNODC, Issue No. 10, CounTer Piracy Programme: Support to Trial and Related Treatment of Piracy Suspects 2 
dozens of Somali pirates convicted in the Seychelles already have been transferred to those prisons to serve their sentences. ${ }^{238}$ If Somali pirates can be returned to Somalia to serve their sentences, they also can be denied asylum.

\section{Somali Piracy and Complementary Informal Sanctions}

As discussed above, scholars argue that the deterrent effect of formal legal sanctions is greater when accompanied by a threat of informal social sanctions. ${ }^{239}$ In the context of Somali piracy, however, evidence indicates that pirates may not regularly or sufficiently be stigmatized by the community from the public exposure as a criminal. Apparently, the members of some communities are not pleased that their youths have taken to hijacking ships in order to enjoy "easy money" and the added benefits of large houses, fast cars, and drugs. ${ }^{240}$ Nevertheless, one cannot say that Somali pirates are being shunned; some seem to envy the pirates' riches. ${ }^{241}$ Moreover, the pirates appear to have obtained the support of some government and other leaders who protect them while they anchor their hijacked ships near shore for months at a time as they await their hefty ransom payments. ${ }^{242}$ This support alone contradicts an environment of stigmatization.

(Dec. 2012), available at https://www.unodc.org/documents/easternafrica/piracy/ CPP_brochure_December_2012.pdf (listing as a UNODC objective the humane imprisonment within Somalia of Somali pirates convicted by foreign nations).

238. See, e.g., EU Offers Support to Kenya, Seychelles for Piracy Trials, EU Bus. (Apr. 26, 2010, 3:39 PM), http://www.eubusiness.com/news-eu/somalia-kenya.4am (noting that the Seychelles' agreement to try pirates requires that convicted pirates serve their sentences in Somalia); Foreign \& Commonwealth Office, Minister for Africa Welcomes the Transfer of Pirates to Somaliland, Gov.uk (Mar. 29, 2012), https://www.gov.uk/government/news/ministerfor-africa-welcomes-the-transfer-of-pirates-to-somaliland (reporting on the transfer of convicted Somali pirates from the Seychelles to Somaliland to serve their sentences); UNODC, Issue No. 11, Counter Piracy Programme: Support to Trial and Related Treatment of Piracy Suspects 3 (Mar. 2013), available at http://www.unodc.org/documents/easternafrica/piracy/UNODC_Brochure_Issue_11_wv.pdf (reporting on the transfer of convicted pirates from the Seychelles to Somalia to serve their sentences).

239. See discussion supra Part III.

240. See A Pirate's Life Is Good in Somalia, supra note 40.

241. See, e.g., Robyn Hunter, Somali Pirates Living the High Life, BBC News (Oct. 28, 2008, 9:16 AM), http://news.bbc.co.uk/2/hi/africa/7650415.stm (quoting a Somali male as saying that "[piracy has] become fashionable" because they are able to "wed the most beautiful girls" and buy large houses and cars); HANSEN, supra note 5, at 40 (quoting a Somali pirate as saying that although he knows that piracy is bad, some people respect and welcome those who hijack ships).

242. See supra notes 56-59 and accompanying text; see also Jama Deperani, Elders Accuse Puntland of Not Fighting Pirates, Somalia RePort (Sept. 19, 2011), http://www.somalia report.com/index.php/post/1598/Elders_Accuse_Puntland_of_Not_Fighting_Pirates 
Yet, creating an environment within Somalia that stigmatizes piracy does not seem impossible. Somali piracy is not the same as the mass-atrocity crimes the commentators highlight when they suggest that existing moral norms may actually compel commission of the crime-indicating that there can be no social stigma to committing the crime. ${ }^{243}$ Not everyone in Somalia is a pirate, and not everyone evidently believes that hijacking ships is proper. Professor Hansen points out that piracy has never become rampant in Somaliland precisely because the authorities have been quick to react to rumors of pirate activity, arresting alleged pirates when they are in the process of organizing. ${ }^{244}$ The Puntland government, by contrast, has not evidenced the same resolve to stamp out piracy. ${ }^{245}$

The problem is that getting government and community leaders in regions where piracy is prevalent to reverse course and condemn piracy could take time. Changing the status quo is not easy, especially when leaders also have a significant financial stake in piracy. Rather than wait for local institutions to fully commit to prosecuting piracy at some date well in the future, the international community could commit to more regularly prosecuting pirates. Prosecuting offenses is critical to stigmatizing maritime piracy-to establish a norm in the moral code that brands the practice reprehensible, as opposed to plentiful and admirable. ${ }^{246}$ As Professor Akhavan suggests in his analysis of the deterrent effect of the ad hoc international criminal tribunals, implementing the process of international justice rather than permitting impunity to reign can produce a sort of "moral propaganda" against committing illegal actions. ${ }^{247}$ Thus, to help create a social stigma against maritime piracy, the international community must regularly punish the pirates it captures rather than release them without requiring them to suffer any repercussions other than the loss of their weapons. ${ }^{248}$ Increasing prosecutions can also give local institutions

(reporting that some elders in the Puntland region were criticizing the government for not putting a stop to piracy).

243. See McAuliffe, supra note 162, at 230.

244. See HANSEN, supra note 5 , at 30 .

245. Id. at 30,33 .

246. See, e.g., Diane Marie Amann, Assessing International Criminal Adjudication of Human Rights Atrocities, 16 Third World Legal Stud. 169, 176 (2003) (noting that prosecutions can have an "expressive" function and strengthen norms against illegal conduct through public reprobation and stigmatization).

247. Payam Akhavan, Beyond Impunity: Can International Criminal Justice Prevent Future Atrocities?, 95 Am. J. INT'L L. 7, 13 (2001).

248. See supra notes $165-73$ and accompanying text. 
the incentive to improve the prosecutorial efforts, because either they embrace the moral message that piracy is wrong or they see their bribes dry up when more pirates are prosecuted. ${ }^{249}$

\section{Conclusion}

Deterrence theory has its critics. Even critics agree, though, that a credible threat of punishment produces a deterrent effect, even if such an effect is difficult to prove. ${ }^{250}$ One cannot even hope to generally and specifically deter crime, though, absent a credible threat of punishment. In the case of Somali piracy, that threat is largely absent because most captured pirates have thus far been released rather than prosecuted. ${ }^{251}$ Strategies aimed at containing the problem of maritime piracy by catching pirates either before or during the act of hijacking ships are commendable because they help protect innocent seafarers from harm. This Article, however, urges states to strive for more: to seek to deter current and future Somali pirates from even choosing to take to the seas by coupling containment efforts with a commitment to prosecute the captured pirates.

This Article argues that increasing prosecutions of captured pirates is a necessary component of any "solution" to the problem of Somali piracy. It is also a plan, as the evidence suggests, that has a likely chance of success. Strategies aimed at improving employment opportunities of Somali males or helping to strengthen weak institutions within Somalia that do not respect the rule of law are not without merit. Yet a strategy focused on increased prosecutions has more to commend it. First, strategies aimed at providing individuals with skills to help them earn a subsistence wage, without more, are unlikely to convince those who seek "easy money" and riches to forswear piracy. Second, strategies aimed at improving local institutions are not likely to work if some individuals within those institutions are tied to piracy and obtain great monetary benefits from its continued existence. Nevertheless, increasing prosecutions has the potential to change the incentives for both the pirates and their collaborators.

Furthermore, the analysis above suggests that Somali pirates are rational individuals who can be deterred by a credible threat of legal sanctions even though they hail from an impoverished country with weak domestic legal institutions. Although they may have

249. See supra notes 203-04 and accompanying text.

250. See supra notes 134-40 and accompanying text.

251. See supra notes $112-15$ and accompanying text. 
few opportunities to obtain the riches that piracy may afford them, the evidence does not suggest that Somali pirates have an atypical risk profile that causes them to be unconcerned with the costs of their activities. Unlike suicide bombers, they do take precautions to minimize risks, for example, and avoid the seas at the roughest and ships they know are protected by armed guards. ${ }^{252}$ Moreover, there is reason to believe that even though they may be poor, Somali pirates would eschew their illegal activities if confronted with a credible threat of certain and severe sanctions. Here, history is a guide. When the ICU made clear that it would punish piracy with death, piracy in Somalia essentially ceased to exist. ${ }^{253}$

Any formal sanctioning regime may best produce a deterrent effect if also coupled with complementary informal sanctions: a social stigma associated with being arrested, tried, and sentenced for engaging in maritime piracy. At present, the hoped-for promise of a social stigma may be hard to come by in the regions in Somalia where piracy is most prevalent. ${ }^{254}$ Abandoning a commitment to prosecuting pirates is not the answer, however. By prosecuting pirates rather than releasing them, the international community can begin to create that social stigma by sending a message that it finds piracy to be the kind of abhorrent activities that must be morally condemned and subjected to criminal punishment.

This Article hopes to convince states and other policy makers that increasing the threat of prosecution is a critical part of an effective and long-term solution to the problem of Somali piracy. It is cognizant that the credible threat of legal sanctions may not deter every individual from choosing a pirate's life. No strategy is perfect. Nevertheless, increasing the costs of piracy through a demonstrated commitment to prosecute rather than release captured pirates has the potential to dissuade at least some Somalis from choosing to seek riches by hijacking ships.

252. See supra Part IV.A.

253. See supra notes 229-34 and accompanying text.

254. See supra notes $245-47$ and accompanying text. 